\title{
Küresel Servet Eşitsizliği ve Çokuluslu Bir Sınıflama Global Wealth Inequality and Multinational Classification
}

\author{
Ercan YAŞAR \\ Dumlupınar Üniversitesi \\ İktisadi ve İdari Bilimler Fakültesi \\ Kütahya, Türkiye \\ orcid.org/0000-0002-9471-4068 \\ ercan.yasar@dpu.edu.tr
}

\author{
Mine YAŞAR
}

orcid.org/0000-0002-1974-4240

mine-demircelik@hotmail.com

\section{Özet}

$\mathrm{Bu}$ çalışmada, küresel boyutta servet dağılımındaki eşitsizlikler ortaya konulmuş ve diğer sosyo-ekonomik adaletsizlikler gibi küresel servetin de benzer bir görünüm sergilediği açıklanmaya çalışılmıştır. Çalışmada, küresel servet eşitsizliği verilerinden ve hane halkı servetinin küresel dağ 1 lımından hareketle servet dağ 1 lımındaki benzer ülkelerin belirlenmesi amaçlanmaktadır. Diğer yandan az gelişmiş, gelişmekte olan ve gelişmiş ülkelerdeki hane halkı servet kompozisyonu arasında farklılıkların izlenmesi amaçlanmıştır. $\mathrm{Bu}$ temel amaçlar doğrultusunda; 171 ülke için benzer servet yapılarına sahip ülkelerin özelliklerinin belirlenmesi sağlanmıştır. Çalışmada incelenen ülkeleri benzerliklerine göre belirli gruplar içinde toplayıp sınıflandırmayı, ülkelerin ortak özelliklerini belirlemeyi amaçlayan Kümeleme Analizi yöntemi kullanılmıştır. Çalışmanın son bölümünde ise Kümeleme Analizi Yöntemi ile elde edilen grupların anlamlılıkları ve grup ayrımlarında etkili olan değişkenleri belirlemek üzere Diskriminant Analizi uygulanmıştır.

Anahtar Kelimeler: Servet Eşitsizliği, Ward Yöntemi, Diskriminant Analizi.

\section{Abstract}

In this study, inequalities in the distribution of wealth at the global level were put forward and it was attempted to explain that global wealth, like other socioeconomic inequalities, displayed a similar appearance. In the study, it is aimed to identify similar countries with wealth distribution by moving from global wealth inequality and global distribution of household wealth. On the other hand, it is aimed to monitor the differences between the wealth composition of households in underdeveloped, developing and developed countries. In line with these basic objectives; It was aimed to determine the characteristics of countries with similar wealth structures for 171 countries. According to the similarities between the units studied in the study, clustering analysis method was used to collect and classify within certain groups, to reveal the common characteristics of the units and to make general definitions about these classes. In the last part of the study, Discriminant Analysis was applied to determine the significance of the groups obtained by the Cluster Analysis Method and the variables that are effective in group distinctions.

Keywords: Wealth Inequality, Ward Method, Discriminant Analysis.

\footnotetext{
* Bu çalışma 10-14 Mayıs 2017 tarihleri arasında Belgrad'da düzenlenen "ICEBSS 2017II. International Conference on Economics Business Management and Social Sciences" kongresinde "A Multivariate, Multinational Comparison of Unequal Wealth of Nations" başlıklı poster olarak sunulan bildirinin geliştirilmiş halidir.
} 


\section{Giriş}

Servet genellikle parayla, tasarruflarla, yatırımlarla, sahip olunan evle, arabayla ya da finansal sermayenin başka biçimleriyle ilişkilendirilir. Bir kişinin veya bir hane halkının serveti, sahip oldukları mal varlıklarıyla ölçülür. Ancak bir kişinin toplam serveti (ya da net serveti) aynı zamanda borçları da içerir. Bu sayede gelir kavramından farklılaşmaktadır. Gelir, akım değişkenken, servet stok değişkendir. Servet, geçmiş harcamaların ve gelirin sonucudur ve aynı zamanda, yatırım, tasarruf ve tüketime ilişkin kararlardan ve miras tarafından etkilenmektedir. Net servet, gelirle güçlü bir ilişki içerisindedir, örneğin yüksek gelir elde eden kişiler, daha fazla tasarruf yapma eğilimindedirler ve bunun sonucunda daha fazla servet biriktirebilirler. Servet, gelirden daha adaletsiz bir şekilde dağılmış olmasına rağmen, servet eşitsizliği, gelir eşitsizliği ile doğrudan ilişkilidir. Servet olarak görülen varlık türleri; arazi, gayrimenkul, tarımsal varlıklar, taşıtlar, nakit para tasarrufları, hayat sigortası birikimleri, emeklilik fonları ve kişisel mülkleri kapsamaktadır (Staunton, 2015, s. 4).

Ülkeler arasında servet dağılımını karşılaştırmak için, aynı servet tanımının yapılması kritik önem taşımaktadır. Servet, hane halklarının sahip olduğu tüm varlıkların ve tüm net borçlarının cari piyasa değeri olarak tanımlanır. Uluslararası standartlara göre; varlıklar, sahiplik haklarının uygulanabildiği ve sahibine ekonomik fayda sağlayan finansal ve finansal olmayan tüm varlıkları kapsamaktadır. Bu tanım tüm emeklilik servetini (eğer bireysel emeklilik hesabı ya da yaşam sigortasına sahipse) içermektedir. Ancak, Sosyal Güvenlik ve tanımlanmamış emekli aylığı hariç tutulmuştur. Servet tanımı, aynı nedenle beşeri sermayeyi de dışlamaktadır (Zucman, 2016, s. 40). Credit Suisse'in servet tanımı, hem mali hem de mali olmayan varlıkları kapsamaktadır. Mali varlıklar yatırım yapılan borç senetleri, hisse senetleri ve nakdi içermektedir. Mali olmayan varlıklar ise ağırlıklı olarak konut ve arsadan oluşan gayrimenkul, küçük işletmeler ve çiftlikleri kapsamaktadır.

\section{Küresel Servet Dağılımı}

Credit Suisse tarafından 2016 yılında yayımlanan Küresel Servet Raporu'na göre; geçtiğimiz yıllara göre, küresel servet \%1,4 artışla 3,5 trilyon dolar artarak 256 trilyon dolara yükselmiştir. Ancak servet yaratma, sadece nüfus artışına ayak uydurmuştur ve bunun sonucunda 2016 yılında yetişkin başına servet, 2008 yılından bu yana ilk kez değişmeyerek yaklaşık 52.800 dolarda kalmıştır. ABD ve Japonya ek servet üretebilmeyi başarmışlar, İngiltere, döviz değer kaybı nedeniyle önemli bir düşüş kaydetmiştir. Küresel Servet Raporu 2008'den bu yana, küresel hane halk1 servetinin, finansal varlıklardaki artışla yönlendirildiğini bildirmektedir. 2016' da, ilk kez finansal olmayan varlıkların artışı nedeniyle, bu eğilimin değişmesi söz konusudur. Toplamda, taşınmaz (aktif-gerçek) varlıklara 4,9 trilyon dolar eklenirken, buna karşın finansal varlıklarda 330 milyar dolarlık bir artış gerçekleşmiştir. Ayrıca rapor, en zengin \%1'lik kesim ile en zengin \%10'luk kesimin payı ile ölçülen servet eşitsizliklerini de ortaya koymaktadır. En zengin \%10'luk kesim servetin \%89'una sahiptir. 2016 Küresel Servet Raporu'na göre, Dünya'nın başlıca ekonomilerine baktığımızda, yetişkin başına düşen servetin en fazla olduğu ülke, İsviçre olmuştur. İsviçre'yi ABD, İngiltere, Fransa, İsveç ve Almanya takip etmektedir. Credit Suisse'in 2016 Küresel Servet Raporu'na göre; Dünya'nın en eşitsiz ülkesi, ulusal servetin \%74,5'ini \%1'lik bir zengin kesimin kontrol ettiği Rusya'dır. Hindistan ve Tayland'da \%1'lik kesim ulusal servetin \%60'ını kontrol altında tutmakta ve Endonezya ve Brezilya'da ise bu oran \%50 civarındadır. 
Uluslararası yardım kuruluşu Oxfam'a ${ }^{1}$ göre en zengin \% 1'lik dilime girenlerin, 2016 'da küresel servetin yarısından fazlasına sahip olduğu belirtilmektedir. Bu kuruluşa göre 2014 yılında dünya nüfusunun \%1'i içindeki yer alan sadece 80 kişinin toplam mal varlığı 1 trilyon 900 milyar dolar olarak hesaplanmıştır ve bu mal varlığı, dünyada yaşayan 3,5 milyar insanın mal varlığından daha fazladır. Daha çarpıcı bir ifadeyle ${ }^{1}$ zenginin mal varlığı 43.750 .000 fakirin mal varlığına karşılık gelmektedir.

Dünya'da 2015 yılında 4,8 milyar yetişkin bireyin sahip olduğu toplam hane halk1 serveti 250,145 trilyon dolara ulaşmıştır. Bu hesaplamayı yapan Credit Suisse kurumunun ilgili raporuna göre yetişkin birey başına düşen ortalama servet ise 52 bin 432 dolar olarak hesaplanmıştır. Ancak, Dünya'da gelir dağılımının eşitsizliğine benzer şekilde, toplam servet de bölgeler, ülkeler ve bireyler arasında eşit oranda dağılmamaktadır. Servetin bölgesel dağılımında aslan payını küresel servetin \%37'si ile Kuzey Amerika ve \% 30 ile Avrupa almaktadır. Çin ve Hindistan dişında Asya-Pasifik bölgesinin toplam servetteki payı \%18 olarak gerçekleşmiştir. Dünya nüfusunun \% 60 'ını barındıran diğer bölgelerin servetteki payı ise sadece \%15'dir.

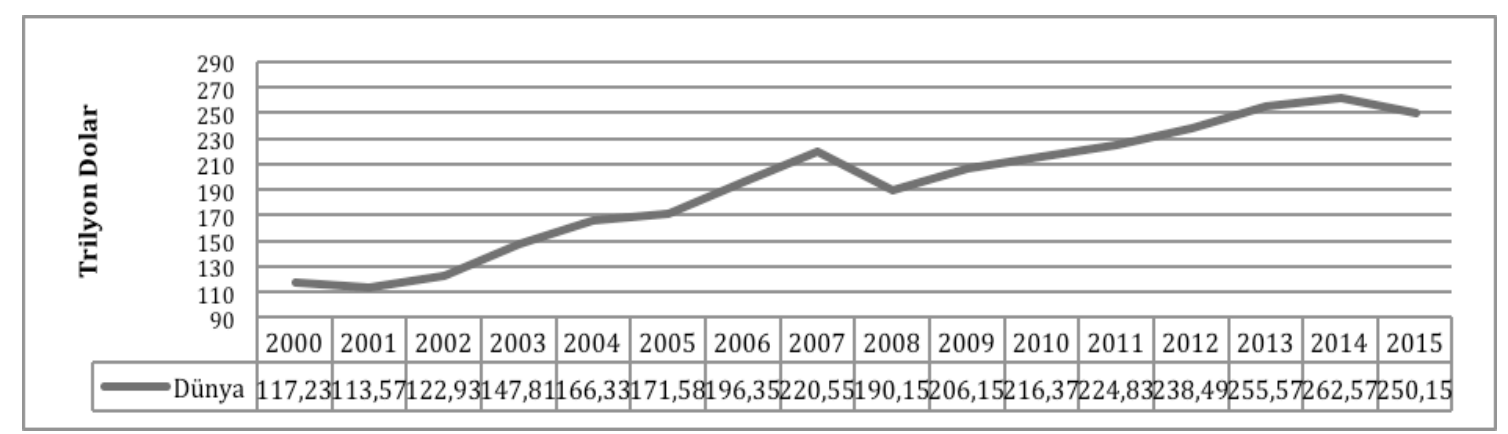

Grafik 1: Dünya küresel servet miktarı (Trilyon Dolar)

Kaynak: Credit Suisse, 2015,Global Wealth Report'dan yazar tarafından oluşturulmuştur.

2015 y1lında küresel servetin toplamı, 2014 yılına göre 12,4 trilyon dolar azalmış ve 250 trilyon dolar olarak gerçekleşmiştir. Bu azalışın en önemli bir nedenin, diğer para birimlerinin ABD doları karşısındaki değer kaybı ve dolayısıyla, bu para birimlerinde ölçülen varlık değerlerinin ABD doları cinsinden karşılıklarının azalması olarak gösterilmektedir.

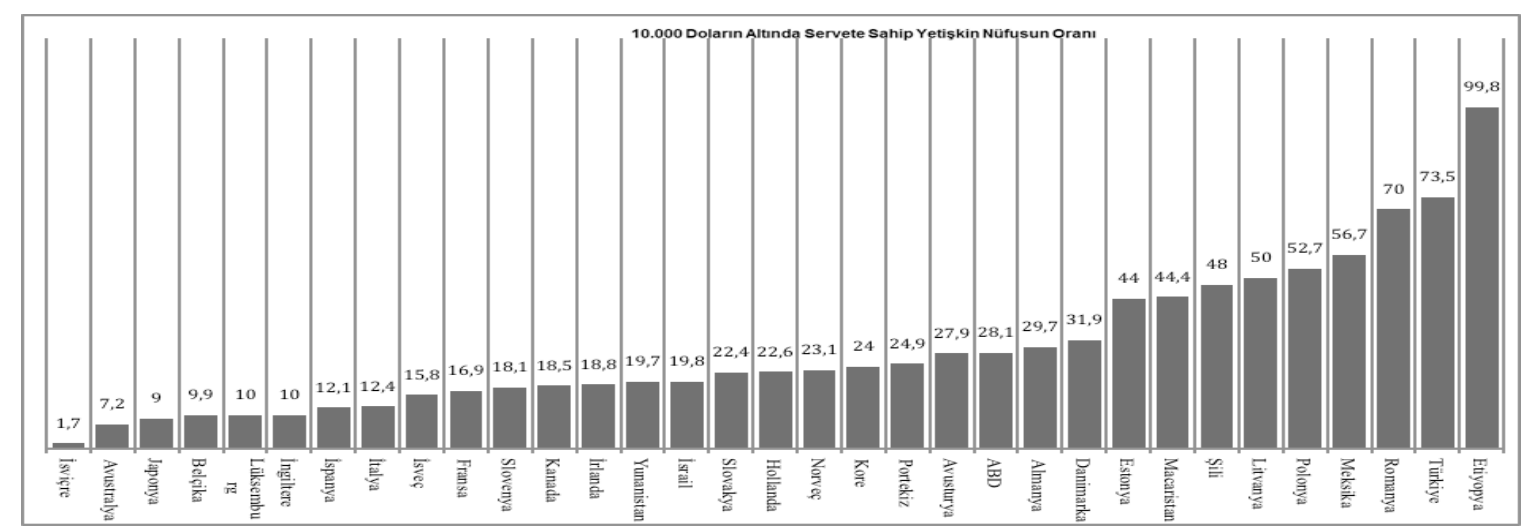

Grafik 2: Seçilmiş ülkelerde 10 bin doların altında servete sahip yetişkin nüfusun oranı (\%)

\footnotetext{
${ }^{1}$ İngiltere'nin Oxford Üniversitesi bünyesinde 1942 yılında kurulan Oxfam, 90 ülkede faaliyet gösteren 17 uluslararası örgütü çatısı altında bir araya getiriyor. Grup, yoksulluğun ortadan kaldırılması, kıtlık, felaketzedelere yardım gibi alanlarda çalışmalar yürütüyor.
} 
Ülkeler bazında da servet eşitsizliği farklılaşabilmektedir. Örneğin; gelir dağılımının daha adaletli olduğu yüksek gelirli bir ülke olan Avustralya'da, servet de, küresel ortalamaya göre daha dengeli bir dağılım göstermektedir. 10 bin dolar altında servete sahip kesim nüfusun pay1 \% 7,2 iken, 1 milyon dolar üstü servete sahip bireylerin nüfustaki payı \% 5,7'dir. Gelir dağılımını gösteren 'Gini katsayısı' ölçütüne göre de $(0=$ tüm gelir eşit dağılmakta, 1 = tüm gelir bir kişi tarafindan kazanılmakta) Avustralya 0,639 ile göreceli olarak adaletli bir dağılım göstermektedir. Diğer taraftan Türkiye'de serveti 10 bin dolar altındaki nüfusun payı $\% 73,5$, serveti 1 milyon doların üstündeki nüfusun payı ise \%0,01'dir Türkiye'nin küresel servet Gini katsayısı da 0,821 değeriyle adaletsiz bir servet dağılımına işaret etmektedir. Ortalama 19,301 dolar olan yetişkin başına servetin de dengesiz dağıldığı görülmektedir. Serveti 10 bin dolar altında olan yetişkin bireylerin toplam yetişkin nüfus içindeki payı \% 73,5'dir. Bu oranla OECD ülkeleri arasında en kötü duruma sahip ülke konumundadır. $\mathrm{Bu}$ oran İsviçre'de \%1,7'dir (Credit Suisse, 2015).

\section{Literatür}

Literatürde servet dağılımı üzerine yapılan çalışmalar, genellikle mikro verilere dayanan, ülke içi servet dağılımındaki adaletsizliklere ve ülke karşılaştırmalarını bu boyutuyla ele alan çalışmalardır. Örneğin; Davies vd. (2009), çalışmalarında; küresel hane halkı servetini ve dağılımını tahmin etmişlerdir. 39 ülke için varlık ve borç seviyeleri hane halkı bilanço ve 2000 yılı anket verileri kullanılarak ölçülmüştür. Servetin hane halkı dağılımı verileri, küresel nüfusun \%59'unu ve küresel servetin yüzde 75'ini oluşturan 20 ülke için toplanmıştır. Bu 20 ülkede servet ve gelir dağılımı arasında gözlemlenen ilişki, birçok başka ulus için üretilecek servet eşitsizliklerine ilişkin tahminleri mümkün kılmaktadır. Çalışmalarında, dünya servetinin \% 71 'ine \%10'luk kesimin sahip olduğunu ve dünya servetinin küresel dağılımına ilişkin Gini katsayısının 0,802 olarak hesaplandığını belirtmişlerdir.

Durand ve Murtin'in (2015) çalışmaları, ortak bir sınıflamaya dayanılarak toplanan OECD Servet Dağıtım Veritabanı'nı kullanarak, 18 OECD ülkesi için hane halkı zenginliğinin dağılımını tanımlamaktadır. Verilerden çıkan sonuç, servet dağılımının en üst düzeyinde, oldukça yüksek bir yoğunlaşma olmasından dolayı, hane halk1 servetinin, hane halkı gelirinden çok daha eşitsiz bir şekilde dağıldığını ortaya koymaktadır. Ortalama olarak ülkeler arasında, en zengin \%10'luk kesim toplam servetin yarısını ellerinde bulundururken, sonraki en zengin \%50'lik kesim, servetin neredeyse diğer yarısında sahiptir. \%60'l1k en fakir kesim ise, servetin yalnızca \%13'üne sahiptir. Ayrıca, hem zengin hem de fakir ülkelerde mikro ekonomik düzeyde gelir ve servet arasında yüksek bir korelasyon bulunmuştur.

Orthofer (2016), 2010-2011 yıllarında yaklaşık 36.000 Güney Afrikalı arasında yapılan anket ve 2010-2011 vergi yılı için yaklaşık 1.2 milyon kişisel gelir vergisi kaydı örneği olmak üzere iki bilgi kaynağını değerlendirerek Güney Afrika servet dağılımı üzerine bir araştırma yapmıştır. Çalışmadan çıkan sonuçlara göre; servet dağılımındaki eşitsizlik, gelir dağılımındaki eşitsizlikten çok daha fazladır. Güney Afrika nüfusunun $\% 1$ 'i, toplam servetin en az yarısını elinde bulundurmaktadır. Yaklaşık 0,95 olarak bulunan Gini katsayısı ile Güney Afrika'da servet eşit olmayan bir şekilde dağılmıştır.

Kuhn vd. (2017), Tüketici Finansları Araştırması'nın (SCF) 1949 yılına kadar uzanan yeni kodlanmış verilerini kullanarak yaptıkları ve 1949-2013 yıllarını kapsayan çalışmalarında ABD hane halkı gelir ve servet dağglımını incelemişlerdir. Daha önceki çalışmaların üst \%10'luk kesimdeki gelir ve servet yoğunlaşmasına daha çok vurgu 
yapıldığını belirten Kuhn vd., çalışmalarında alt \%90'lık kesimin gelir ve servet yoğunluğundaki artışı resmetmeyi amaçlamışlardır. Çalışmaya göre, gelir eşitsizliği, servet eşitsizliğinden daha önce ve daha güçlü bir şekilde artmıştır. Hane halkı portföyündeki farklılıklar, gelir ve servet eşitsizliklerinin gözlemlenmesinde önemli bir rol oynamaktadır. Bu farklılıklar, 1990'lı ve 2000'li yillarda ev fiyatlarındaki patlamalardan elde edilen kazançlarda önemli bir farklılığa yol açmıştır.

Richardson ve Denniss (2014), Avustralya'da gelir ve servet eşitsizliğini ortaya koyan, vergi sistemi ve hükümet politikalarına da odaklanan çalışma; hem gelir hem de servet açısından en zenginle en fakir kesim arasındaki eşitsizliğin arttığını göstermektedir. Ayrıca çalışma, vergi ve aktarım sisteminin, eşitsizliği azaltmakta etkili bir şekilde geliri yeniden dağıtma kapasitesine sahip olduğuna dair açık bir kanıt sağlar niteliktedir.

\section{Veri ve Yöntem}

Literatürdeki çalışmalardan farklı olarak bu çalışmada, ülkelerin küresel servet kompozisyonlarının birbirlerine göre ne durumda olduklarını belirlemek amaçlanmıştır. $\mathrm{Bu}$ amaç doğrultusunda; çok boyutlu istatistiki yöntemlerin kullanılması gerekmektedir. $\mathrm{Bu}$ nedenle verilerin düzenlenip hazır hale getirilmesi, istenilen gruplandırmanın yapılabilmesi ve oluşturulan grupların geçerliliğinin test edilmesi amacıyla da SPSS-21 for Windows istatistik paket programı kullanılmıştır. Ülkeleri gruplara ayırmada Aşamalı Kümeleme Analizi (Hierarchical Cluster Analysis) yöntemi uygulanmıştır. Ayrıca analizde veri seti -1 ve +1 arasında standardize edilirken, Ward tekniği uygulanmış ve değişkenler öklit kare uzaklıklarına göre analiz edilmişlerdir. Küresel servet dağılımının incelenebilmesi amacıyla Credit Suisse'nin 2016 yılı Küresel Servet Raporu'ndan derlenen ve aşağıda listelenen 10 farklı değişken kullanılmıştır. Küme üyelikleriyle ilgili dendogram sonuçlarına göre ülkelerin 5 kümede ele alınması uygun görülmüştür.

\section{Tablo 1: Veri Seti}

Değișken

1. Toplam Servet (USD)

2.Yetişkin Başına Servet (USD)

3. Yetişkin Başına Finansal Servet (USD)

4.Yetişkin Başına Finansal Olmayan Servet (USD)

5.Yetişkin Başına Borç (USD)

$6.10,000$ USD ve aşağısı servete sahip nüfus (\%)

7.10000-100000 USD arası servete sahip nüfus (\%)

8.100,000 -1 milyon USD arası servete sahip nüfus (\%)

9.1 milyon USD ve üzeri servete sahip nüfus (\%)

10. Servet Gini Katsayıs1 \%
Veri Kaynağı

Credit Suisse, 2016,Global Wealth Report Credit Suisse, 2016,Global Wealth Report

Credit Suisse, 2016,Global Wealth Report Credit Suisse, 2016,Global Wealth Report Credit Suisse, 2016,Global Wealth Report Credit Suisse, 2016,Global Wealth Report Credit Suisse, 2016,Global Wealth Report Credit Suisse, 2016,Global Wealth Report Credit Suisse, 2016,Global Wealth Report Credit Suisse, 2016,Global Wealth Report

Daha sonra belirlenen grupların anlamlılığını tespit etmek için Ayırma Analizi (Discriminant Analysis) yöntemi kullanılmıştır. Ayırma analizi, belirlenmiş olan kümeleme değişkenlerinin, incelenen ülkelerin kümelenmesini ne ölçüde başardığını göstermektedir. Ayırma analizini kümeleme analizinden ayıran temel fark, ayırma analizinde grupların önceden biliniyor olmasıdır (Özdamar, 2004, ss. 355-356). 


\section{Kümeleme Analizi ve Ward Yöntemi}

Kümeleme analizi yönteminde gözlenen birimlerin (bu araştırmada ülkelerin) ölçülen tüm değişkenler üzerindeki değerlerini hesaplamak ve aralarındaki benzerlikleri belirlemek amacıyla uzaklık, korelasyon veya kategorik verilerin benzerlik ölçüleri kullanılmaktadır. Analizin sonucunda bir kümeyi oluşturan birimlerin ortak özelliklere sahip olduğu ve diğer kümelerdeki birimlerin özelliklerinin ise birbirlerinden farklılaştığı görülecektir. Bunun anlamı; kümelerin kendi içerisinde homojen olduğu; kümeler arasında ise heterojenliğin söz konusu olduğudur. Kümelemenin başarılı olduğu durumlarda, çok boyutlu uzayda gösterildiğinde, aynı küme içinde yer alan birimlerin birbirine oldukça yakın olduğu görülmektedir; kümelemenin başarılı olmadığı durumlarda ise, farklı kümeler birbirinden oldukça uzakta görülecektir

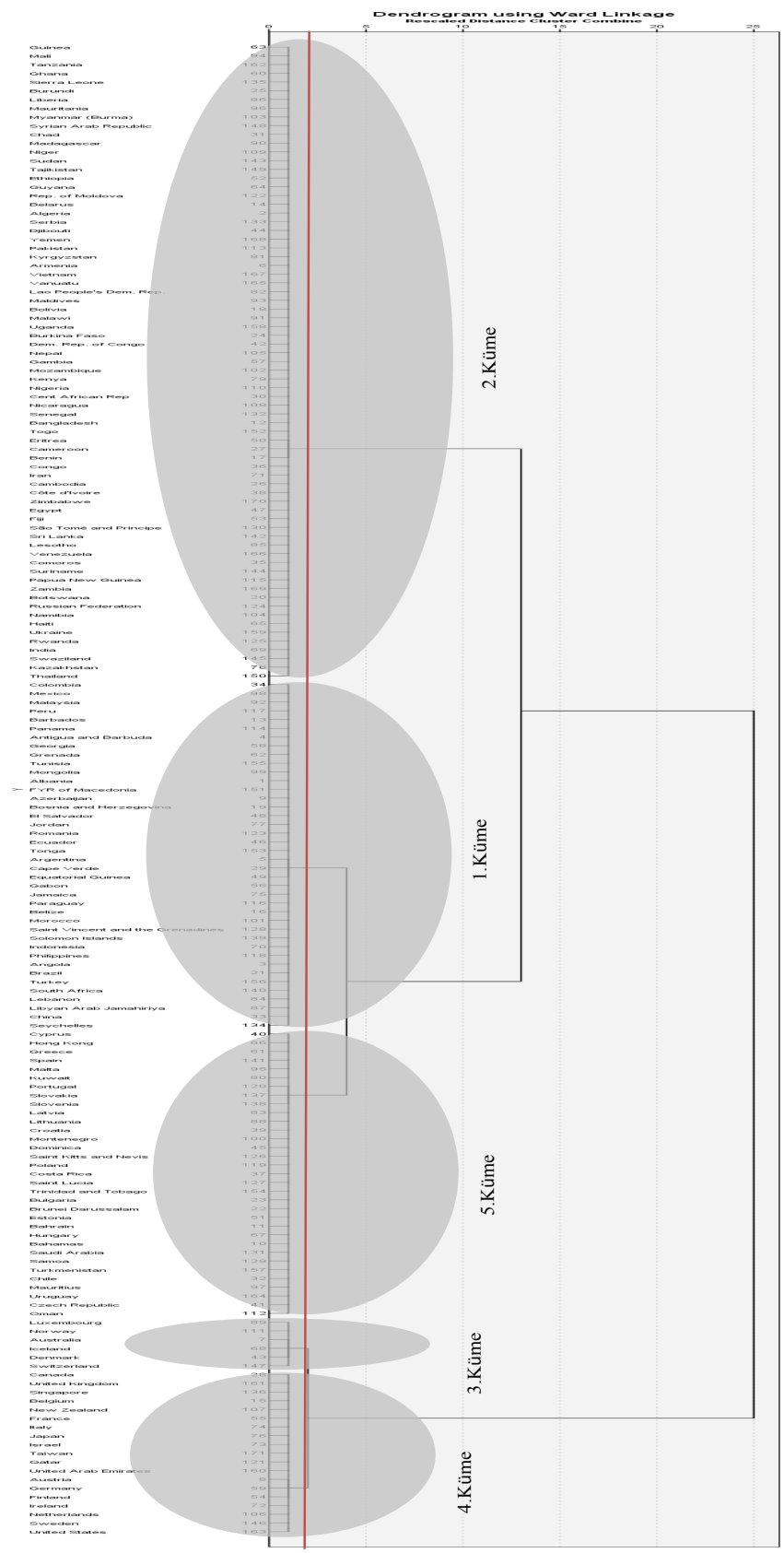
(Turanlı vd, 2006, s. 97; Güngör, 1999, s. 123). Kümeleme analizini uygulamadan önce kümeleme yönteminin seçimine karar verilmesi önemlidir. Kümeleme analizi, veri matrisinde yer alan ve doğal gruplamaları kesin olarak bilinmeyen birimleri, değişkenleri ya da birim ve değişkenleri birbirleriyle benzer olan alt kümelere ayırmaya yardımcı olan yöntemler topluluğudur. (Firuzan vd, 2010, ss. 107-108). Kümeleme analizinde, genellikle küme sayısı önceden bilinmediği için yalnızca verilerin mevcut durumundan yola çıkarak kümeler elde edilir; bundan dolayı da sonuçlar gelecek tahmininde kullanılmamaktadır. Şunu belirtmek gerekir ki; kümeleme analizinde verilere ilişkin normallik varsayımı olmasına rağmen, yalnızca uzaklık değerlerinin normalliği yeterli görülmektedir (Turanlı vd., 2006, s. 97). Yukarıda da belirtildiği gibi Kümeleme analizi, doğal siniflamaları olmayan durumlarda popülasyonda olas1 alt grup yapılarını tahmin etmekte kullanılan yöntemler topluluğudur; doğal gruplamaları önceden bilinen popülasyonlarda alt kümelerin incelenmesi Ayırma Analizi ile yapılır (Özdamar, 2004, s. 280). 


\section{Kümeleme Yönteminin Belirlenmesi}

Kümeleme analizi temelde; "Hiyerarşik Kümeleme" ve "Hiyerarşik Olmayan Kümeleme" olarak ikiye ayrılmaktadır. Hiyerarşik kümeleme, aşamalı olarak gerçekleşen ve ağaca benzer bir yapı oluşturmaktadır. Bu yöntem, Birleştirici ve Ayırıcı olarak ikiye ayrılmaktadır. Birleştirici aşamalı kümeleme yöntemlerinde birimlerin birleştirilmesinde farklı yaklaşımlar kullanılmaktadır. En yaygın kullanımı olan Ward yöntemidir. Ward yönteminde grup içi homojenlik en çoklanarak kümeler oluşturulur. Küme içi kareler toplamı, homojenliğin ölçüsü olarak alınır. Bu yöntemde amaç küme içi kareler toplamını en küçüklemektir. Hiyerarşik kümeleme yöntemleri çok büyük örneklemleri analiz etmede uygun değildirler (Öz vd, s. 2009). Bu çalışmada da incelenen ülke sayısı 171 olmasından dolayı birbirine benzer ülke gruplarını belirlemek amacıyla hiyerarşik kümeleme analizi kullanılmıştır.

En Küçük Varyans Bağlantı Kümeleme Yöntemi olarak da bilinen Ward Yöntemi Centroid ve Medyan bağlantı küme yöntemlerinin karma ve ağırlıklı biçimidir ve küme içindeki en küçük varyansı optimum kılmak için tasarlamıştır. Bu nedenle grup içi kareler toplamı veya hata kareler toplamı olarak da bilinir (Everitt vd, 2010, s. 77). Wishard (1969), küme merkezleri arasındaki kareli Öklid Uzaklıklar matrisini kullanarak Ward metodunun nasıl kullanılacağını matematiksel olarak göstermiştir (Yaylalı vd, 2005, ss. 5-6).

\section{Analiz ve Bulgular}

$\mathrm{Bu}$ çalışmada, ülkelere ait servet verileri değişken olarak göz önüne alınmış ve hiyerarşik kümeleme yöntemlerinden biri olan Ward kümeleme yöntemine karar verilmiştir. Klasik kümeleme yöntemleri küme sayısını önceden vermemektedir. Küme sayısının belirlenebilmesi için dendogramlar ve grafik yöntemler kullanılmaktadır. Yukarıdaki şekilde Ward metoduna göre çizilen dendogram görülmektedir. Soldan sağa birbirine birbirine eşit 25 birim olarak ölçeklendirilen dendogramda birbirlerine en çok benzeyen ülkeler en kısa mesafede bir araya gelmektedir. Mesafe arttıkça benzerliğe bağlı olarak ilk oluşan kümeye yeni ülke ya da ülke grubu dahil olur. Birbirine en az benzeyen birimlerin ise en uzak mesafede bir araya geldiği görülmektedir (Tekin, 2015, s. 14). Mesafe 25 birime geldiği zaman tek bir küme oluşmaktadır ve tüm ülkeler bu küme içerisinde yer almaktadır. $\mathrm{O}$ halde mesafe ve küme sayısı, araştırmanın niteliğine ve amacına göre, optimum bir seviyede belirlenmelidir. Yukarıdaki şekildeki dendogramdan görülebileceği gibi 171 ülkeye ait servet ile ilişkili 10 değişkenin 5 kümede farklılaştığı görülmektedir. Bu dendograma bakılarak 5 adet kümenin uygun olduğu söylenebilir. Grafiksel yöntemle küme sayısı araştırılırken önce 2 küme çözümü, daha sonra 3 küme çözümü ve bütünlük bozulana kadar diğer küme çözümleri sırayla denenmiştir ve 5 küme çözümünde karar kılınmıştır ${ }^{2}$. Şekilde görülen dendogramda 2 küme çözümünde dendograma göre 3. ve 4. kümelerin ortak bir küme oluşturdukları ve 1,2. ve 5. kümelerin ise ortak diğer ikinci kümeyi oluşturdukları izlenmektedir. 3 küme çözümünde ise, 1. ve 5. kümelerin tek küme oluşturduğu, 3. ve 4. kümelerin tek bir küme oluşturduğu ve son olarak 2. kümenin tek başına ayrı bir küme oluşturduğu izlenmektedir.

\footnotetext{
${ }^{2}$ Her bir aşamadaki küme çözümlerine ilişkin aşamalı küme üyelikleri Ek-1'de verilmiştir.
} 
Tablo 2: Ward Yöntemine Göre 5 Kümenin Küme Üyelikleri

\begin{tabular}{|c|c|}
\hline $\begin{array}{l}\text { 1. Küme } \\
\text { (40 üye) }\end{array}$ & $\begin{array}{l}\text { Arnavutluk, Angola, Antigua ve Barbuda, Arjantin, Azerbaycan, Barbados, Belize, Bosna Hersek, } \\
\text { Brezilya, Cape Verde, Çin, Kolombiya, Ekvador, El Salvador, Ekvator Ginesi, Gabon, Gürcistan, } \\
\text { Grenada, Endonezya, Jamaika, Ürdün, Lübnan, Libya, Malezya, Meksika, Moğolistan, Fas, Panama, } \\
\text { Paraguay, Peru, Filipinler, Romanya, Saint Vincent ve Grenadinler, Seyşeller, Solomon Adaları, } \\
\text { Güney Afrika, Makedonya Cum., Tonga, Tunus, Türkiye }\end{array}$ \\
\hline $\begin{array}{l}\text { 2. Küme } \\
\text { (73 Üye) }\end{array}$ & $\begin{array}{l}\text { Cezayir, Ermenistan, Bangladeş, Belarus, Benin, Bolivya, Botsvana, Burkina Faso, Burundi, } \\
\text { Kamboçya, Kamerun, Mrk. Afrika Cum., Çad, Komoros, Kongo, Fildişi Sahili, Dem. Kongo Cum., } \\
\text { Cibuti, Misır, Eritre, Etiyopya, Fiji, Gambiya, Gana, Gine, Guyana, Haiti, Hindistan, İran, Kazakistan, } \\
\text { Kenya, Kırgızistan, Lao Halk Dem. Cum., Lesotho, Liberya, Madagaskar, Malawi, Maldivler, Mali, } \\
\text { Moritanya, Mozambik, Myanmar (Burma), Namibya, Nepal, Nikaragua, Nijer, Nijerya, Pakistan, } \\
\text { Papua Yeni Gine, Moldova, Rusya Federasyonu, Ruanda, Sao Tome ve Principe, Senegal, Sirbistan, } \\
\text { Sierra Leone, Sri Lanka, Sudan, Surinam, Svaziland, Suriye, Tacikistan, Tayland, Togo, Uganda, } \\
\text { Ukrayna, Tanzanya, Vanuatu, Venezuela, Vietnam, Yemen, Zambiya, Zimbabve. }\end{array}$ \\
\hline $\begin{array}{l}\text { 3. Küme } \\
\text { (6 Üye) }\end{array}$ & Avustralya, Danimarka, İzlanda, Lüksemburg, Norveç, İsviçre \\
\hline $\begin{array}{l}\text { 4. Küme } \\
\text { (19 Üye) }\end{array}$ & $\begin{array}{l}\text { Avusturya, Belçika, Kanada, Finlandiya, Fransa, Almanya, İlanda, İsrail, İtalya, Japonya, Hollanda, } \\
\text { Yeni Zelanda, Katar, Singapur, İsveç, Birleşik Arap Emirlikleri, İngiltere, A.B.D., Tayvan. }\end{array}$ \\
\hline $\begin{array}{l}\text { 5. Küme } \\
\text { (33 Üye) }\end{array}$ & $\begin{array}{l}\text { Bahamalar, Bahreyn, Bulgaristan, Şili, Kosta Rika, Hırvatistan, Kıbrıs, Çek Cum., Dominika, } \\
\text { Estonya, Yunanistan, Hong Kong, Macaristan, Kuveyt, Letonya, Litvanya, Malta, Mauritius, Karadağ, } \\
\text { Umman, Polonya, Portekiz, Saint Kitts ve Nevis, Saint Lucia, Samoa, Suudi Arabistan, Slovakya, } \\
\text { Slovenya, İspanya, Trinidad ve Tobago, Türkmenistan, Uruguay }\end{array}$ \\
\hline
\end{tabular}

Aşağıda yığışım diyagramı katsayılarına göre çizilen grafikte 5 küme çözümünün uygun olduğu görülmektedir.

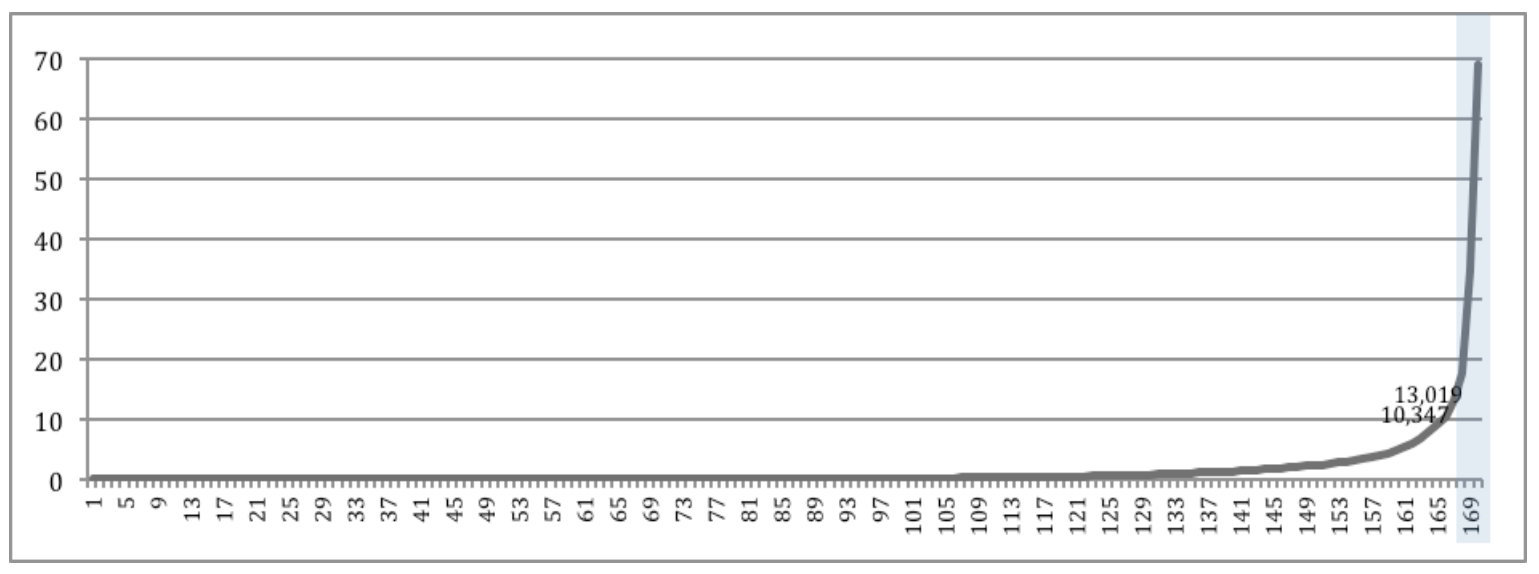

Grafik 4: Yı̆̆ı̆ı̧ım Diyagramı

\section{Diskriminant Analizi Sonuçları}

Yukarıda Ward Kümeleme analizi ile elde edilen 5 küme çözümü verilmiştir. Çalışmanın bundan sonraki aşamasında Ayırma (Discriminant Analizi) uygulanarak, Ward yöntemi ile ortaya çıkan kümelerin ne kadar başarılı bir şekilde ayrıldığı test edilmeye çalış1lacaktır. Diskriminant Analizi, matematiksel tekniklerle grupların birbirinden en iyi şekilde ayrılmasını sağlamaktadır. Bir başka deyişle, bağımsız değişkenlerin değerlerine bağlı olarak, hangi birimin hangi grupta yer aldığını ve ne kadar iyi tahmin edildiğini göstermektedir. Diskriminant Analizi, büyük bağımsız değişkenler seti ile bağımlı değişkenler arasında ilişkinin ortaya çıkarılması için uygun bir yöntemdir. Bundan dolayı, çalışmanın bundan sonraki aşamasında yukarıda belirlenen kümelerin tanımlanması amacıyla Diskriminant Analizi yapılması uygun görülmüş̧ür (Kamışlı ve Girginer, 2010, s. 13). Küresel Servet Raporundan elde edilen ve ülkelerin servet kompozisyonlarını temsil ettiği düşünülen 10 değişken ile küme 
sayısı hakkında öncül bir bilgiye sahip olunmadığından Hiyerarşik Küme Yöntemlerinden Ward yöntemi uygulanmış ve bu yönteme göre 5 kümenin uygun olacağı görülmüştür. Diskriminant analizinin birinci amacı, bu 10 değişkene göre Ward Yöntemi ile elde edilmiş 5 kümenin ortalamalarının anlamlı fark gösterip göstermediğini belirlemektir. Ward yönteminde kullanılan değişkenler ile Diskriminant analizi uygulanarak böyle bir gruplama yapılıp yapılmayacağına veya bu grupların farklılaşıp farklılaşmadığına karar verilecektir. İkinci amaç; Diskriminant analizi ile 5 kümeyi birbirinden ayıran en önemli değişkeni ve önemsiz değişkenleri saptamaktır (Öztürk ve Yıldız, 2012, s. 29). Diskriminant analizinin üçüncü amacı, 10 değişken için diskriminant değerlerine göre sınıflandırmaktır. Diskriminant analizi, kümeler arası varyans/ küme içi varyans oranını maksimize ederek bu amacı gerçekleştirmektedir. Bu oranın maksimum olması, kümeler arası varyansın en büyük, küme içi varyansın ise en küçük olması durumunda gerçekleşecektir. Bu durumda ülkeler birbirinden farklılık gösterecek şekilde sınıflandırılmaktadır. Böylece, farklılaşan ülkeleri ortaya çıkarmada, bu koşulu sağlayan ülkelere ait bağımsız değişkenler de saptanabilecektir.

\section{Diskriminant Analizi Bulgular}

Ward Kümeleme analizinde de kullanılan toplam 10 bağımsız değişken ile analiz gerçekleştirilmiştir. Küresel servet dağılımının tanımlayıcı istatistikleri 5 küme için her bir kümenin ortalamaları ve standart sapmaları Tablo 3'de verilmiştir. Grup ortalamaları, değişkenlerin ortalamalarının gruplar arasında farklı olup olmadı̆̆ hakkında bir fikir vermektedir. Buna ek olarak, grup ortalamaları ve grup standart sapmaları, 5 grup için özellik profili çıkartmak için kullanılabilir. Tablo 3 grup ortalamaları değişkenler için farklı olduğunu göstermektedir:

Tablo 3: Küme Ortalamaları ve Standart Sapmaları

\begin{tabular}{|c|c|c|c|c|c|c|c|c|c|c|}
\hline \multirow[t]{2}{*}{ Değişkenler } & \multicolumn{2}{|c|}{ 1. Küme } & \multicolumn{2}{|c|}{ 2. Küme } & \multicolumn{2}{|c|}{ 3. Küme } & \multicolumn{2}{|c|}{ 4. Küme } & \multicolumn{2}{|c|}{ 5. Küme } \\
\hline & Ortalama & $\begin{array}{c}\text { Standart } \\
\text { Sapma }\end{array}$ & Ortalama & $\begin{array}{c}\text { Standart } \\
\text { Sapma } \\
\end{array}$ & Ortalama & $\begin{array}{c}\text { Standart } \\
\text { Sapma }\end{array}$ & Ortalama & $\begin{array}{c}\text { Standart } \\
\text { Sapma }\end{array}$ & Ortalama & $\begin{array}{c}\text { Standart } \\
\text { Sapma }\end{array}$ \\
\hline Toplam Servet & 883 & 3691 & 107 & 389 & 2072 & 2461 & 9530 & 19328 & 346 & 789 \\
\hline $\begin{array}{l}\text { Yetişkin Başına } \\
\text { Servet }\end{array}$ & 17844 & 9003 & 3416 & 2705 & 372440 & 106418 & 223881 & 55769 & 52204 & 39814 \\
\hline $\begin{array}{l}\text { Yetişkin Başına } \\
\text { Finansal Servet }\end{array}$ & 6386 & 5257 & 1275 & 1255 & 207363 & 92636 & 140216 & 52126 & 26509 & 26644 \\
\hline $\begin{array}{l}\text { Yetişkin Başına } \\
\text { Finansal Olmayan } \\
\text { Servet }\end{array}$ & 13859 & 6421 & 2438 & 2215 & 262771 & 69546 & 125019 & 35327 & 36035 & 26543 \\
\hline $\begin{array}{l}\text { Yetişsin Başına } \\
\text { Borç }\end{array}$ & 2402 & 2573 & 296 & 478 & 97694 & 25644 & 41353 & 14953 & 10339 & 11867 \\
\hline $\begin{array}{l}\text { 10,000 Dolar ve } \\
\text { Altı Servete Sahip } \\
\text { Nüfusun Oranı }\end{array}$ & 69,3 & 7,9 & $\mathbf{9 5 , 9}$ & 3,6 & 24,0 & 10,5 & 23,8 & 6,5 & 39,3 & 11,9 \\
\hline $\begin{array}{l}\text { 10000-100000 } \\
\text { Arası Servete } \\
\text { Sahip Nüfusun } \\
\text { Oranı }\end{array}$ & 28,6 & 7,3 & 3,8 & 3,4 & 19,7 & 7,6 & 31,7 & 6,8 & 52,0 & 7,2 \\
\hline $\begin{array}{l}\text { 100,000 -1 Milyon } \\
\text { Dolar Arası servete } \\
\text { Sahip Nüfusun } \\
\text { Oranı }\end{array}$ & 1,93 &, 77 & ,25 & ,21 & 49,6 & 6,26 & 41,3 & 8,25 & 8,2 & 7,09 \\
\hline $\begin{array}{l}\text { 1 Milyon Dolar ve } \\
\text { Üzerinde Servete } \\
\text { Sahip Nüfusun } \\
\text { Oranı }\end{array}$ & ,13 & ,09 & ,01 &, 03 & 6,6 & 2,57 & 3,09 & 1,13 & ,41 & ,44 \\
\hline $\begin{array}{l}\text { Servet Gini \% } \\
\text { Katsayısı }\end{array}$ & 77,3 & 5,59 & 79,6 & 7,76 & 76,13 & 7,53 & 73,96 & 6,00 & 70,40 & 7,05 \\
\hline Küme Üye Sayıları & & & & & 0 & & 1 & & & \\
\hline
\end{tabular}


Normal dağılım, eşit kovaryans, çoklu bağlantı olmaması, diskriminant analizinin optimal olabilmesi ve yanlış sınıflandırmayı en aza indirmek için sağlanması gereken üç varsayımdır. Yapılan normallik testleri sonucunda "Servet Gini Katsayısı" değişkeni dışındaki değişkenlerin normal dağılıma sahip olmadıkları görülmüştür. Logaritmik dönüşümü yapılan tüm değişkenler için normal dağılımı sağladıkları, basıklık ve çarpıklık değerlerinin $(-1,+1)$ arasında olduğu görülmüştür. Ancak çalışmanın ilk bölümünde Ward yöntemine göre kümelenen değişkenler logaritmik dönüşüme tabi tutulmadığından, Diskriminant Analizi için de dönüştürülmemiş değişkenler kullanılmıştır.

Diskriminant analizini yapmak için temel varsayımlardan bir diğeri, ortalamalarının büyük ölçüde farklı olmasına rağmen grupların eşit varyans-kovaryans matrislerine sahip olmalarıdır. Bu varsayım, Box's $\mathrm{M}$ testi ile sinanır. Bu testte sifir hipotezi $\left(\mathrm{H}_{0}\right)$, grupların varyans-kovaryans matrislerinin aynı olmasıdır. 0.00'luk bir Pdeğeri (sig), boş hipotezin reddedildiği anlamına gelir; dolayısıyla, varsayımın ihlal edildiği anlamına gelir. Bununla birlikte, 0.05 'den küçük bir değer, diskriminant fonksiyonun tahmini olasılığını otomatik olarak iptal etmez. Her ne kadar varsayım ihlal edilmiş olsa da, çoğu zaman, diskriminant fonksiyonu, geçerlik kontrolü sırasında geçerli bulunabilir. Bu varsayımın ihlali, sapan değerler nedeniyle olması durumunda büyük bir örneklem boyutu ile çalışılıyorsa, modelin yüksek doğruluk oranı ile tahminine bir sorun teşkil etmez. Tabachnick ve Fidell, (1996) eğer ihlal, sapan değerlerden (outliers) kaynaklı bir çarpıklık (Skewness) nedeniyle değilse bunun bir problem olmadığını, eğer örneklem büyüklüğünden kaynaklanıyorsa bu durumda da ayırma fonksiyonlarının tahmini geçerliliğine bakılarak, örneklemin isabet oranına göre kontrol edilebileceğini belirtmişlerdir.

Diskriminant analizinde öncelikle grup kovaryans matrislerinin eşitliği varsayımının veri seti üzerinde geçerliliğini test etmek amacıyla, Box's M testi yapılmıştır. Anlamlı Box-M istatistiği, eşit olmayan kovaryans matrislerini veya normallikten sapmayı veya her ikisini göstermektedir (Albayrak, 2006, s. 63; Görener, 2013, s. 155).

Veriler Box-M istatistiği ile test edildiğinde sonuç kovaryans matrislerinin eşit olmadığını göstermektedir. (Box's $\mathrm{M}=3575,791, \mathrm{~F}=29,193, \mathrm{p}<0,000$ ). Box's $\mathrm{M}$ testi sonucuna göre gruplar arası varyans kovaryans matrisleri homojen değildir $(p=0.000)$. Kovaryans matrisleri homojenliği varsayımı sağlanamadığında, bu varsayımı kullanmayan karesel (quadratic) diskriminant analizi uygulanmasının uygun olacağ belirtilmiştir (Boyacıŏlu ve Kara, 2007, s. 207). Bu nedenle ayrı kovaryans matrislerine (havuzlanmış kovaryans matrisinin öngörülen kullanımı yerine) göre sınıflandırma seçilir (Firuzan vd, 2010, s. 112). Ayrı kovaryans matrislerini kullanmak, kovaryans matrislerinin eşitsizlik problemini ortadan kaldırmanın bir yoludur. Ayrı kovaryans matrislerini kullanarak gerçekleştirilen sınıflandırma sonuçları, kuadratik diskriminant analiz sonuçlarına benzer sonuçlar vermektedir (Saithanu vd, 2014, s. 76; Dechaume-Moncharmont vd, 2011, s. 80). Bununla birlikte, anlamlılık oranı (p-değeri) çok düşük olduğu için, değişkenlerin tek değişkenli normallikleri kontrol edilmiştir. Çünkü diskriminant analizi sapan değerlere oldukça duyarlı bir analizdir. Bu nedenle, sapan değerler belirlenmeli ve analizden çıkarılmalıdır (Uddin vd, 2013, s. 157). Değişkenlerin tek değişkenli normallik testi sonuçlarına göre, bazı değişkenlerin çoğunun normal dağılım izlemediğini göstermektedir. Çalışmada kullanılan gözlem sayısı az olduğu için (171 ülke), normal dağılmayan değişkenlere ait gözlemler 
analizlerden çıkarılmamıştır. Aynı zamanda gözlem sayısının arttırılması da (neredeyse ana kütle ile çalışıldığından) mümkün değildir. Değişkenlerin normal dağılıma uymayan gözlemleri temizlendiğinde daha yüksek isabet oranına sahip ve daha iyi tahmini ayırt edicilik fonksiyonları elde edilebilir. Ancak sapan değerlerin temizlenmesi gözlem sayısının azalmasına yol açacak ve aynı zamanda ABD, İsviçre, Japonya, İzlanda gibi önemli bilgi içeren gözlemlerin dışarıda bırakılması anlamına gelecektir. Uddin ve arkadaşlarına göre (2013); bu varsayımın ihlal edilmesi ayırma fonksiyonlarının tahmini geçerliliği, örneklemin isabet oranına göre kontrol edilebilir. Bu nedenle bu ülkeler analizden çıkarılmadan diskriminant analizinin sonraki aşamalarına geçilmiştir.

Bir diğer varsayım; diskriminant analizinde bağımsız değişkenler arasında çoklu doğrusallık olmamasıdır. Korelasyon matrisi, değişkenlerin çoklu doğrusallığını kontrol etmek için kullanılabilir. Buna ek olarak, bir bağımsız değişken ile bağımsız değişkenlerin geri kalanı arasındaki ilişki kontrol edilmelidir. Çoklu doğrusallık problemi, aşamalı diskriminant analizi kullanılarak da çözülebilir. Verilerde çoklu doğrusallık bulunursa düzeltilmelidir (Uddin vd, 2013, s. 157). Değişkenler arasındaki çoklu doğrusal bağlantıyı test etmek için yapılan tolerans testlerine göre "Yetişkin Başına Borç" ve "100.000-1 Milyon Dolar Arasında Servete Sahip Nüfusun Oranı" değişkenleri diskriminant analizinden çıkarılmıştır.

Diskriminant analizinde fonksiyonların ne kadar önemli olduğunun belirlenmesinde Öz Değer, Kanonik Korelasyon ve Wilks' Lambda istatistiklerine bakılmaktadır (Altuntaş ve Tan, 2017, s. 381). Bu istatistikler oluşturulan fonksiyonların grupları anlamlı olarak birbirinden ayırıp ayıramadığını göstermektedir. Öz değer, diskriminant analizinin ne kadar değerli olduğunu değerlendirmede kullanılan bir istatistiktir. Öz değerler, bağlı değişkendeki varyansın fonksiyonların her biri tarafından ne kadarlık bir bölümünün açıklanabileceğini göstermektedir (Oğuzlar, 2006, s.79). Öz değerin "0" olması, diskriminant analizinin herhangi bir ayırıcılık değerinin olmadığını gösterir. Kalaycı (2005); kesin bir değer olmamakla birlikte 0.40 'tan büyük öz değerler iyi olarak kabul edilebileceğini belirtmiştir. Kanonik korelasyon değerleri ise, 0.0 ve 1.0 arasında değerler alarak, fonksiyonun gruplar arasında ne kadar iyi ayrımc1 olduğunun göstergesi durumundadır. Başka bir ifadeyle kanonik korelasyon, diskriminant skorları ve gruplar arasındaki ilişkiyi ölçer ve toplam varyansı gösterir. Gruplar arasındaki fonksiyonun iyi bir ayrımcı olabilmesi için, yüksek kanonik korelasyon değerleri elde edilmelidir (Kamışlı ve Girginer, 2010, s. 14-15).

Tablo 4: Diskriminant Analizi İçin Özdeğerler ve Kanonik Korelasyonlar.

\begin{tabular}{|ccccc|}
\hline & \multicolumn{5}{c|}{ Özdeğerler } \\
Fonksiyon & Özdeğer & Varyansın \% & Birikimli \% & Kanonik Korelasyon \\
1 & $18,320^{\mathrm{a}}$ & 62,7 & 62,7 &, 974 \\
2 & $8,546^{\mathrm{a}}$ & 29,3 & 92,0 &, 946 \\
3 & $2,279^{\mathrm{a}}$ & 7,8 & 99,8 &, 834 \\
4 &, $058^{\mathrm{a}}$ &, 2 & 100,0 &, 233 \\
\hline
\end{tabular}


Tablo 2'de görüldüğü gibi Ward Kümeleme yöntemine göre başlangiçta belirlenen beş grup olduğu için 4 diskriminant fonksiyonu oluşturulmuştur. Özdeğerin büyük olması bağımlı değişkendeki varyansın daha büyük bir kısmının elde edilen fonksiyon tarafından açıklanabildiğini göstermektedir. Kanonikal diskriminant fonksiyonları toplam varyansın \%100'ünü açıklamaktadır. Tablo 4'de görüldügüü üzere, birinci diskriminant fonksiyonu öz değeri 18,320 iken, toplam varyansın \%62,7'sini açıklamakta, ikinci diskriminant fonksiyonu öz değeri 8,546 ve toplan varyansın \%29,3'ünü açıklamakta ve üçüncü fonksiyon öz değeri 2,279 ve varyansın \% \%,8'ini açıklamaktadır. İlk üç fonksiyonun değeri istatistiki bakımdan anlamlıdır. Birinci fonksiyonun Kanonik Korelasyonu 0,97 ikinci fonksiyonun ise 0,94' ve üçüncü fonksiyon ise \%83'dür. Burada ilk fonksiyona ait Kanonik Korelasyon Katsay1s1 0.974 olarak elde edilmiştir. Katsayının karesi $\left(\mathrm{r}^{2}\right)$ 0.948'dir. Bağımsız değişkenlerin bağımlı değişkeni \% 94,8 oranında açıkladığı görülmüştür. İkinci fonksiyona ait Kanonik Korelasyon Katsayısı 0.946 olup, bağımlı değişkendeki varyansın \% 89,4'ünü açıklayabilmektedir. Üçüncü fonksiyona ait Kanonik Korelasyon Katsayısı 0.834; bağımlı değişkendeki varyansın \% 69,5'ini açıklamaktadır.

Wilks' Lambda istatistiği ise, diskriminant skorlarındaki toplam varyansın gruplar arasındaki farklar tarafından açıklanamayan kısmını (oranını) gösterir. Lambda'nın "1" olması, gözlenen grup ortalamalarının farklı olmadığını gösterirken, 1'den küçük değerler ise grup ortalamalarının farklı olduğunu göstermektedir.

Tablo 5: Wilks' Lambda Değerleri

\begin{tabular}{|lcccc|}
\hline & \multicolumn{4}{c|}{ Wilks' Lambda } \\
Fonksiyon Testi & Wilks' Lambda & Ki-Kare & Serbestlik Derecesi & Anlamlılık Düzeyi \\
1 through 4 &, 002 & 1056,325 & 32 &, 000 \\
2 through 4 &, 030 & 572,179 & 21 &, 000 \\
3 through 4 &, 288 & 203,296 & 12 &, 000 \\
4 &, 946 & 9,151 & 5 &, 103 \\
\hline
\end{tabular}

Diskriminant analizinde bağımsız değişkenlerin önemlerinin değerlendirilmesinde, diskriminant fonksiyonu katsayıları ve yapı matrisindeki her bir bağımsız değişkenin yükü önemlidir. Tablo 5'de Wilks' Lambda değerlerine göre; birinci fonksiyonun değeri 0,000 anlamlılık düzeyinde 0,002 (yani toplam varyansın $\% 0,02$ 'si) ve ikinci fonksiyonun değeri 0,000 anlamlılık düzeyinde 0,03 (yani toplam varyansın $\% 0,3$ 'ü) ve üçüncü foksiyonun 0,000 anlamlılık düzeyinde 0,288 (yani toplam varyansın yaklaşık \%29'u) gruplar tarafından açıklanamamaktadır. İlk üç fonksiyon grupları anlamlı bir şekilde ayırabilmiştir. İlk üç fonksiyonun değeri istatistiki bakımdan anlamlıdır $(\mathrm{P}<0.01$ ve $\mathrm{P}<0.05)$. Anlamlılık düzeyine bakıldığında diskriminant fonksiyonlarının ayırt etme gücü anlamlı bulunmaktadır.

Seçilen değişkenlerin grupları anlamlı olarak ayırıp ayırmadığını test etmek için değişkenlerin Wilks' Lambda ve F istatistikleri hesaplanmıştır. Böylece, bağımsız değişkenlere göre beş kümede anlamlı farklılık gösterip göstermediği test edilmiştir. Test sonuçlarına göre 8 değişken için kümeler arasındaki farkların tümünün 0,05 anlamlılık düzeyinde anlamlı olduğu görülmektedir. Bir bağımsız değişkene ilişkin Wilks' Lambda değeri küçüldükçe, o değişken diskriminant fonksiyonuna o kadar fazla katkıda bulunduğu söylenebilir. Wilks' Lambda değeri 0 ile 1 arasında değer alır. Bu değer " 0 " eşit olursa küme ortalamalarının farklı olduğu, eğer " 1 " eşit olursa küme 
ortalamalarının benzer olduğu ya da küme ortalamaları arasında ayrım olmadığ1 anlamına gelir (Zor ve Akın, 2008, s. 189). Sekiz değişkenin Wilks' Lambda değerlerine göre; 1'e en yakın değerler alan "Toplam Servet" ve "Servet Gini \% Katsayısı" değişkenlerinin kümeleri ayırmada etkisiz oldukları, diğer değişkenlerin ise kümeleri ayırmada etkili değişkenler olduğu yorumu yapılabilir. Fakat ayırmada en etkili faktörün hangisi olduğuna karar vermek için standartlaştırılmış diskriminant fonksiyonlarının ve yapı matrisin incelenmesi gerekmektedir.

Tablo 6: Diskriminant Analizi Sonucu Elde Edilen Wilks' Lambda Grup Ortalamalarının Eşitliği Testi

\begin{tabular}{|l|c|c|c|c|c|}
\hline & Wilks' Lambda & F & df1 & df2 & Sig. \\
\hline Toplam Servet &, 837 & 8,097 & 4 & 166 &, 000 \\
\hline Yetişkin Başına Servet &, 107 & 346,841 & 4 & 166 &, 000 \\
\hline Yetişkin Başına Finansal Servet &, 187 & 180,196 & 4 & 166 &, 000 \\
\hline Yetişkin Başına Finansal Olmayan Servet &, 113 & 326,887 & 4 & 166 &, 000 \\
\hline 10,000 Dolar ve Altı Servete Sahip Nüfusun Oranı &, 066 & 588,196 & 4 & 166 &, 000 \\
\hline $10000-100000$ Arası Servete Sahip Nüfusun Oranı &, 091 & 412,749 & 4 & 166 &, 000 \\
\hline 1 Milyon Dolar ve Üzerinde Servete Sahip Nüfusun Oranı &, 145 & 245,624 & 4 & 166 &, 000 \\
\hline Servet Gini \% Katsayıs1 &, 795 & 10,723 & 4 & 166 &, 000 \\
\hline
\end{tabular}

Tablo 7: Kanonikal Diskriminant Katsayıları

\begin{tabular}{|c|c|c|c|c|}
\hline \multicolumn{5}{|c|}{ Standartlaştırılmış Kanonik Diskriminant Fonksiyon Katsayıları } \\
\hline & \multicolumn{4}{|c|}{ Fonksiyon } \\
\hline & 1 & 2 & 3 & 4 \\
\hline Toplam Servet (Dolar) &,- 279 &,- 056 &,- 032 &,- 533 \\
\hline Yetişkin Başına Servet (Dolar) & 2,842 & 1,714 & $-3,784$ & 1,204 \\
\hline Yetişkin Başına Finansal Servet (Dolar) &,- 946 & $-1,139$ & 1,865 & 1,275 \\
\hline Yetişkin Başına Finansal Olmayan Servet (Dolar) &,- 946 & $-1,014$ & 2,831 & 699 \\
\hline 10,000 Dolar ve Alt1 Servete Sahip Nüfusun Oranı & 1,943 & ,628 & 1,400 & 1,223 \\
\hline 10000-100000 Dolar Arası Servete Sahip Nüfusun Oranı & ,943 & 1,412 & 1,201 & 677 \\
\hline 1 Milyon Dolar ve Üzerinde Servete Sahip Nüfusun Oranı & $-1,188$ &,- 074 & ,900 & $-2,146$ \\
\hline Servet Gini \% Katsayıs1 &,- 100 &, 127 &,- 160 &,- 787 \\
\hline
\end{tabular}

Standartlaştırılmış ayırma fonksiyonu katsayıları, regresyon analizindeki beta katsayıları ile aynı amaca hizmet etmektedir. Diğer bir ifadeyle, bağımlı değişkenin tahmininde bağımsız değişkenin göreceli önemini göstermektedir. Standartlaştırılmış katsayıların kullanılmasının sebebi, bağımsız değişkenlerdeki farklı ortalamalar ve farklı standart sapmaların etkilerini ortadan kaldırmaktır (Karagül ve Özdemir, 2009, s. 56, Oğuzlar, 2006, s. 82). Zor ve Akın (2008) standart olmayan kanonik diskriminant katsayılarının, sınıflandırmada kullanılacak olan diskriminant değerlerinin hesaplanmasında kullanıldığını ve bu katsayıların, her bir değişkenin diskriminant değerlerinin hesaplanmasındaki mutlak katkısını göstermekle birlikte, değişkenlerin katkılarını birbirleriyle karşılaştırılmasında yanıltıcı olabildiklerine dikkat çekmişlerdir. Değişkenlerin standart sapmalarının farklı olması, bir değişkendeki bir birimlik değişimin diğer bir değişkendeki bir birimlik değişimden farklı anlam taşıdığını göstermektedir. Bundan dolayı, her bir değişkenin ayırma fonksiyonuna katkısı karşılaştırılırken standart diskriminant katsayıları kullanılmaktadır. $\mathrm{Bu}$ nedenlerle standartlaştırılmış ayırma fonksiyon katsayıları, değişkenlerin fonksiyon üzerindeki etkisinin değerlendirilmesinde korelasyonlara tercih edilmesi gerekir (Zor ve Akın, 2008, s. 192). Standartlaştırılmış katsayılar incelendiğinde "Yetişkin Başına Servet" 
değişkeni, modelin ilk iki fonksiyona en fazla katkıda bulunan faktör olarak ortaya çıktığı görülmektedir. İlk fonksiyon için; "Yetişkin Başına Servet (Dolar)", "10,000 Dolar ve Altı Servete Sahip Nüfusun Oranı", "1 Milyon Dolar ve Üzerinde Servete Sahip Nüfusun Oranı"nın en etkili değişkenler olduğu, diğer değişkenlerin etkisiz olduğu görülmektedir.

Diskriminant fonksiyonunu yazabilmek için, kanonik diskriminant katsayılarının incelenmesi gerekmektedir. Diskriminant fonksiyonunun belirlemek için elde edilen 3 adet fonksiyon ve fonksiyon içerisinde bulunan değişkenlerin standartlaştırılmamış katsayılardan türetilen ayırma fonksiyonu şu şekildedir:

Fonksiyon: 1

$\mathrm{Z} 1=-20,953-0,000042 \mathrm{X} 1+0,000090 \mathrm{X} 2-0,000036 \mathrm{X} 3-0,000046 \mathrm{X} 4+0,258853 \mathrm{X} 5+$ 0,160083 X6 -1,925228 X7 -0,014332 X8

Fonksiyon:2

$\mathrm{Z} 2=-12,337425-0,000009 \mathrm{X} 1+0,000054 \mathrm{X} 2-0,000043 \mathrm{X} 3-0,000049 \mathrm{X} 4+0,083597 \mathrm{X} 5+$ $0,239629 \times 6-0,120063 \times 7+0,018164 \times 8$

Fonksiyon: 3

$Z 3=-17,001939-0,000005 X 1-0,000119 X 2+0,000071 X 3+0,000137 X 4+0,186554 X 5+$ $0,203830 \times 6+1,458608 \times 7-0,022877 \times 8$

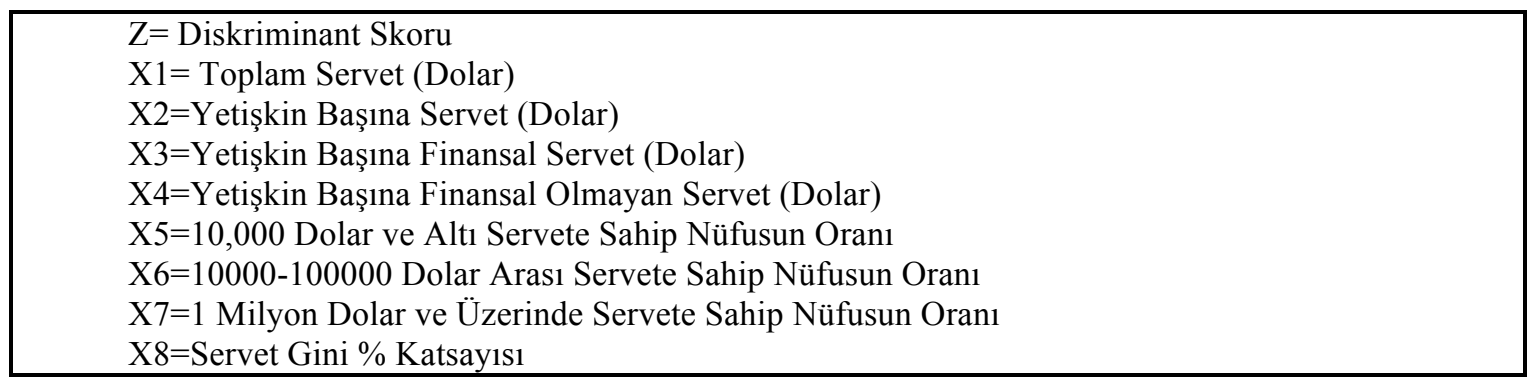

Yapı matrisinin katsayıları, faktör yüklemeleri veya kanonik yüklemeler olarak bilinir. Bir faktör yüklemesi, değişken ve tahmini ayırt edicilik fonksiyonu arasındaki korelasyonu temsil eder. Bir faktör yüklemesinin karesi ile değişkenin bağımlı değişkende açıklayabileceği değişimi belirleyebiliriz. Katsayı ne kadar büyük olursa, grup üyeliğinin belirlenmesinde o kadar önemlidir. Dolayısıyla, analizde bağımsız değişkenlerin öneminin değerlendirilmesinde, katsayının mutlak boyutu kullanılmaktadır (Yüksel, 2004, s. 53). Yapı matrisi, matriste yer alan her bir değişkenin ayırma fonksiyonu ile olan korelasyonunu gösterilmektedir.

Tablo 8: Yapı Matrisi

\begin{tabular}{|lcccc|}
\hline & \multicolumn{4}{c|}{ Fonksiyon } \\
10,000 Dolar ve Altı Servete Sahip Nüfusun Oranı & 1 & 2 & 3 & 4 \\
Yetişkin Başına Servet (Dolar) &, $823^{*}$ &,- 450 &, 125 &,- 266 \\
Yetişkin Başına Finansal Olmayan Servet (Dolar) &,$- 638^{*}$ &,- 324 &, 073 &, 032 \\
1 Milyon Dolar ve Üzerinde Servete Sahip Nüfusun Oranı &,$- 610^{*}$ &,- 311 &, 320 &, 047 \\
Yetişkin Başına Finansal Servet (Dolar) &,$- 506^{*}$ &,- 358 &, 245 &,- 168 \\
10000-100000 Arası Servete Sahip Nüfusun Oranı &,$- 456^{*}$ &,- 246 &,- 050 &, 080 \\
Servet Gini \% Katsayısı &,- 434 &, $871^{*}$ &, 051 &, 212 \\
Toplam Servet (Dolar) &, 078 &,- 120 &, 008 &,$- 624^{*}$ \\
\hline
\end{tabular}

Yap1 matrisi değişkenlerin grup üyeliklerini belirlemede en önemliden en düşük öneme sahip olana göre düzenlenmiştir. Bir değişkenin katsayısının karesi, bağımlı 
değişkende bir değişken tarafından açıklanabilen varyasyon hesaplanabilir. Örneğin, “10.000 dolar altı servete sahip nüfus oranı" için grup üyeliklerinde \% 82,3'lik (= $0,6773) \%$ değişimi açıklayabilir.

Tahmin edici özelliğe sahip olan değişkenlere bakıldığında, fonksiyon ile 0.20 'den daha az ilişkisi tespit edilen değişkenlerin, önemli olmadıkları söylenebilir. Tablo 8'de verilen sonuçlara bakıldığında, birinci fonksiyon ile en yüksek korelasyona sahip bağımsız değişkenin "10.000 Dolar Altı Servete sahip nüfusun oranı" (0.823) olduğu, en düşük korelasyona sahip bağımsız değişkenin ise "Toplam Servet" (-0.075) olduğu görülmektedir. İkinci fonksiyon ile en yüksek korelasyona sahip bağımsız değişkenin "10.000-100.000 Dolar Arası Servete Sahip Nüfus Oranı" (0.871) olduğu, en düşük korelasyona sahip bağımsız değişkenin ise "Toplam Servet" (-0.035) olduğu; üçüncü fonksiyon ile en yüksek korelasyona sahip bağımsız değişkenin "Yetişkin Başına Finansal Olmayan Servet" (0.320) olduğu, en düşük korelasyona sahip bağımsız değişkenin ise "Servet Gini Katsayısı" (0.008) olduğu görülmektedir. Birinci fonksiyon için önemsiz değişkenler "10.000-100.000 Dolar Arasında Servete Sahip Nüfusun Oranı", "Servet Gini Katsayısı" ve "Toplam Servet" değişkenleri olmuştur. İkinci fonksiyon için ise tek önemli değişken "10.000-100.000 Dolar Servete Sahip Nüfusun Oranı" olduğu görülmektedir.

Tablo 9: Ayrıştırma Fonksiyonları Ağırlıkları

\begin{tabular}{|c|c|c|c|c|c|}
\hline & \multicolumn{5}{|c|}{ Ward Yöntemi } \\
\hline & 1 & 2 & 3 & 4 & 5 \\
\hline Toplam Servet (Dolar) &,- 003 &,- 004 &,- 003 &,- 003 &,- 003 \\
\hline Yetişkin Başına Servet (Dolar) & ,005 & 006 & ,003 & ,005 &, 005 \\
\hline Yetişkin Başına Finansal Servet (Dolar) &,- 001 &,- 001 & ,000 &,- 001 &,- 001 \\
\hline Yetişkin Başına Finansal Olmayan Servet (Dolar) &,- 001 &,- 001 & ,001 & ,000 &,- 001 \\
\hline 10,000 Dolar ve Altı Servete Sahip Nüfusun Oranı & 18,666 & 19,005 & 15,736 & 15,529 & 18,230 \\
\hline 10000-100000 Arası Servete Sahip Nüfusun Oranı & 18,126 & 17,611 & 15,198 & 15,209 & 18,410 \\
\hline 1 Milyon Dolar ve Üzerinde Servete Sahip Nüfusun Oranı & $-130,111$ & $-137,050$ & $-98,519$ & $-119,074$ & $-126,649$ \\
\hline Servet Gini \% Katsayıs & 383 & 235 & 246 & 481 &, 402 \\
\hline (Sabit) & $-954,189$ & $-963,140$ & $-782,465$ & $-706,146$ & $-941,757$ \\
\hline
\end{tabular}

Diskriminant analizinin başarısı, doğru sınıflandırma yüzdesine bağlıdır; bu oran ne kadar yüksek ise yapılan analizin o kadar başarılı olduğu söylenebilir. Tablo 10' daki sonuçlar incelendiğinde, 171 ülkenin 165'inin $(\%$ 96,5'i) doğru bir şekilde sınıflandırılmış olduğu görülmektedir. Diskriminant fonksiyonunun toplam doğru sınıflandırma yüzdesi oldukça başarılı bir orana işaret etmektedir. Analiz sonucunda elde edilen fonksiyonlardan; 1. kümede yer alan 40 gözlem biriminin 38'i doğru atanmış, 2'si hatalı sınıflandırılmıştır (2. kümeye atanmıştır). 2 kümede yer alan 73 gözlem biriminin tamamı doğru atanmıştır. 3. kümede yer alan 6 gözlem biriminin 5'i doğru kümede 1 gözlem ise hatalı olarak (4. küme). 4. kümede yer alan 19 gözlemin tamamı doğru kümeye atanmıştır. Son olarak 5. kümedeki 33 ülkenin 30’u doğru, 3’ü hatalı yerleştirilmiştir. Bu sonuçlar doğrultusunda tahmin edilen küme üyeliklerinin \%96,5'i doğru tahmin edilmiştir. Hatalı küme yerleştirmelerinin ikinci en iyi küme olasılıkları doğru tahmin edilmiş ve aşağıdaki tabloda verilmiştir. 
Tablo 10: Çapraz Geçerlilik Yöntemi ile Ward Yöntemine Göre Elde Edilen Kümelerin Sınıflama Sonuçları

\begin{tabular}{|c|c|c|c|c|c|c|c|c|}
\hline \multirow[b]{2}{*}{ Ward Yöntemi } & & & \multicolumn{5}{|c|}{ Tahmin Edilen Küme Üyelikleri } & \multirow[b]{2}{*}{ Toplam } \\
\hline & & & 1 & 2 & 3 & 4 & 5 & \\
\hline \multirow[t]{10}{*}{ Original } & \multirow[t]{5}{*}{ Count } & 1 & 38 & 2 & 0 & 0 & 0 & 40 \\
\hline & & 2 & 0 & 73 & 0 & 0 & 0 & 73 \\
\hline & & 3 & 0 & 0 & 5 & 1 & 0 & 6 \\
\hline & & 4 & 0 & 0 & 0 & 19 & 0 & 19 \\
\hline & & 5 & 3 & 0 & 0 & 0 & 30 & 33 \\
\hline & \multirow[t]{5}{*}{$\%$} & 1 & 95,0 & 5,0 & 0,0 & 0,0 & 0,0 & 100,0 \\
\hline & & 2 & 0,0 & 100,0 & 0,0 & 0,0 & 0,0 & 100,0 \\
\hline & & 3 & 0,0 & 0,0 & 83,3 & 16,7 & 0,0 & 100,0 \\
\hline & & 4 & 0,0 & 0,0 & 0,0 & 100,0 & 0,0 & 100,0 \\
\hline & & 5 & 9,1 & 0,0 & 0,0 & 0,0 & 90,9 & 100,0 \\
\hline \multirow[t]{10}{*}{ Cross-validated $^{b}$} & \multirow[t]{5}{*}{ Count } & 1 & 37 & 3 & 0 & 0 & 0 & 40 \\
\hline & & 2 & 0 & 73 & 0 & 0 & 0 & 73 \\
\hline & & 3 & 0 & 0 & 5 & 1 & 0 & 6 \\
\hline & & 4 & 1 & 0 & 0 & 18 & 0 & 19 \\
\hline & & 5 & 3 & 0 & 0 & 0 & 30 & 33 \\
\hline & \multirow[t]{5}{*}{$\%$} & 1 & 92,5 & 7,5 & 0,0 & 0,0 & 0,0 & 100,0 \\
\hline & & 2 & 0,0 & 100,0 & 0,0 & 0,0 & 0,0 & 100,0 \\
\hline & & 3 & 0,0 & 0,0 & 83,3 & 16,7 & 0,0 & 100,0 \\
\hline & & 4 & 5,3 & 0,0 & 0,0 & 94,7 & 0,0 & 100,0 \\
\hline & & 5 & 9,1 & 0,0 & 0,0 & 0,0 & 90,9 & 100,0 \\
\hline
\end{tabular}

Diskriminant analizi sonuçları 6 ülkenin grubunu hatalı yerleştirmiş olup, bu ülkelerin ikinci en yüksek olasılıklarda doğru yerleştirdiği görülmektedir. Bu ülkeler sirasiyla; 23.Bulgaristan (5-1), 70.Endonezya (1-2), 89.Lüksemburg (3-4), 118.Filipinler (1-2), 127. Saint Lucia (5-1), 154 Trinidad - Tobago (5-1) şeklinde siralanabilir.

Tablo 11: Hatalı Yerleştirilen Gözlemler ve İkinci En Yüksek olasılıklı Grup

\begin{tabular}{|c|c|c|c|c|c|c|c|c|c|}
\hline \multirow{3}{*}{ Gözlem } & \multirow{3}{*}{$\begin{array}{l}\text { Ward } \\
\text { Yöntemi } \\
\text { Sonucu } \\
\text { Elde } \\
\text { Edilen } \\
\text { Grup }\end{array}$} & \multicolumn{5}{|c|}{ En yüksek Olasılıklı Grup } & \multicolumn{3}{|c|}{$\begin{array}{c}\text { İkinci En Yüksek Olasılıklı } \\
\text { Grup }\end{array}$} \\
\hline & & \multirow{2}{*}{$\begin{array}{l}\text { Tahmin } \\
\text { Edilen } \\
\text { Grup }\end{array}$} & \multicolumn{2}{|c|}{$\begin{array}{c}P(D>d \mid \\
G=g)\end{array}$} & \multirow{2}{*}{$\begin{array}{l}P(G=g \\
\mid D=d)\end{array}$} & \multirow{2}{*}{$\begin{array}{c}\text { Kareli } \\
\text { Mahalanobis } \\
\text { Centroid } \\
\text { Uzaklığı }\end{array}$} & \multirow{2}{*}{ Grup } & \multirow{2}{*}{$\begin{array}{l}P(G=g \\
\mid D=d)\end{array}$} & \multirow{2}{*}{$\begin{array}{c}\text { Kareli } \\
\text { Mahalanobis } \\
\text { Centroid } \\
\text { Uzaklığı }\end{array}$} \\
\hline & & & p & df & & & & & \\
\hline 23: Bulgaristan & 5 & $1^{* *}$ & ,326 & 4 & ,825 & 4,644 & 5 & 175 & 7,746 \\
\hline 70: Endonezya & 1 & $2^{* *}$ & ,258 & 4 &, 561 & 5,300 & 1 & ,439 & 5,789 \\
\hline 89: Lüksemburg & 3 & $4^{* *}$ & ,000 & 4 & 647 & 37,653 & 3 & 353, & 38,864 \\
\hline 118:Filipinler & 1 & $2^{* *}$ &, 515 & 4 & ,925 & 3,260 & 1 & ,075 & 8,271 \\
\hline 127: Saint Lucia & 5 & $1^{* *}$ & ,519 & 4 & 935 & 3,234 & 5 & ,065 & 8,569 \\
\hline 154 Trinidad- Tobago & 5 & $1^{* *}$ & ,454 & 4 & ,886 & 3,663 & 5 & 114 & 7,767 \\
\hline
\end{tabular}

Tablo 12'de her bir kümenin ortalama ayırma fonksiyon değeri görülmektedir. Centroidler her bir değişken için ortalama skorlardır. Centroidlerin işaretleri yorumlamada önemlidir. Zit işaretli grupların o değişken üzerinde ayrıştırıldığı söylenmektedir. $\mathrm{Bu}$ farklılıklar ANOVA'daki çoklu karşılaştırmalar gibi 
yorumlanabilir. İlk iki diskriminant fonksiyonuna göre grup dağılımları aşağıda gösterilmiştir.

Tablo 12: Ayrıştırma Fonksiyonları Grup Ortalamaları (Centroids)

\begin{tabular}{|c|c|c|c|c|}
\hline \multirow[t]{2}{*}{ Ward Yöntemi } & \multicolumn{4}{|c|}{ Fonksiyon } \\
\hline & 1 & 2 & 3 & 4 \\
\hline 1 & ,926 & 1,710 & ,391 &,- 396 \\
\hline 2 & 3,465 & $-1,945$ &,- 117 &, 107 \\
\hline 3 & $-11,701$ & $-6,724$ & 5,634 &, 000 \\
\hline 4 & $-7,791$ & $-1,914$ & $-3,014$ &,- 047 \\
\hline 5 & $-2,174$ & 4,555 & ,495 & 270 \\
\hline
\end{tabular}

Aşağıda sınıflandırma haritasına göre en önemli ilk iki fonksiyon değerleri göz önüne alınarak grupların dağılımları gösterilmiştir (Altuntaş ve Tan, 2017, s. 386). Sınıflandırma haritasına göre gruplar toplam 5 kümeye ayrılmıştır. Sınıflandırma haritası kümelerin belirlenmesi grup numaraların karşılıklı olarak oluşturularak kendi içinde alan oluşturmuştur. Grubu oluşturan ülkelerin ataması ise kanonik diskriminant aracılığıyla olmaktadır. Sınıflama grup dağılımlarının yatay ekseninde 1. kanonik diskriminant fonksiyonu, dikey ekseninde 2. kanonik diskriminant fonksiyonu oluşturmaktadır.

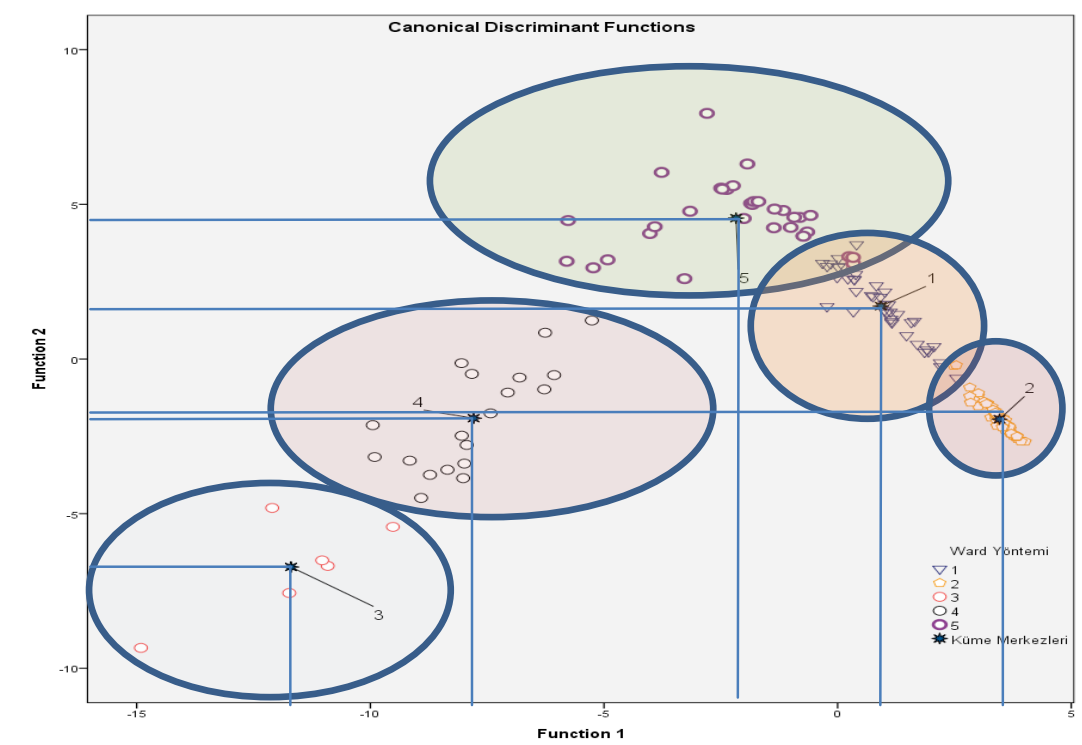

Grafik: 5 Kanonik Ayrıştırma Fonksiyonları Grup Ortalamaları ve Uzaklıkları

\section{Sonuç ve Tartışma}

Credit Suisse'nin 2016 y1lı Küresel Servet Raporu'na göre ülkelerin servet birikimlerinin göstergesi olan ve yukarıda listelenen 10 farklı değişken ile yürütülen Kümeleme Analizi sonuçları, küresel servet bileşenlerine göre ülkelerin 5 farklı kümede sınıflanabileceğini göstermiştir. Ward yönteminin kullanıldığg Kümeleme analizine göre gelişmiş Avrupa ülkelerinin ve Amerika'nın aynı küme içerisinde (4. Küme) yer aldı̆̆ı, aynı zamanda petrol zengini Katar ile Birleşik Arap Emirlikleri'nin bu kümede yer aldığı görülmektedir. Güney Amerika'nın doğusu ile genellikle Afrika ülkelerinin yer aldığ 1 Rusya Federasyonu ve Kırgızistan'1 da içine alan 2. kümenin oluştuğu, Türkiye'nin de içerisinde yer aldığ 1 . kümenin oluştuğu ve son olarak Doğu Avrupa ülkeleri ve bazı Orta ve Güney Doğu Asya ülkelerinin oluşturduğu görülmektedir. Bu sonuçlar açısından kümeleme sonuçlarının gelişmişlik düzeyi ile paralellik arz ettiği 
söylenebilir. Ancak analiz sonuçlarında 3. kümenin neden 4. kümeden ayrıldı̆̆ ayrıntılı analizler ile ortaya konmalıdır.

Araştırmada, analiz edilen ülkelerin servet yapılarını belirleyen diskriminant fonksiyonları elde edilmiştir. Aşamalı diskriminant analizi sonucunda, ülkelerin servet yapılarını belirlemede önemli ayırma özelliğine sahip diskriminant fonksiyonları ile 1 . kümeye ait ülkeler $\% 95,2$. kümeye ait ülkeler $\% 100,3$. kümeye ait ülkeler \%83,3, 4. kümeye ait ülkeler \%100 ve 5. kümeye ait ülkeler \%90,9 doğrulukla ayırılabileceği saptanmıştır. Bu sonuç kurulan modelin başarılı olduğunu göstermektedir. Diskriminant analizi sonucunda, ülkelerin servet değişkenlerine göre ayırmaya en fazla katkısı olan bağımsız değişkenler birinci diskriminant fonksiyonuna göre "10.000 Dolar Altı Servete Sahip Nüfusun Oranı" olmuştur. İkinci diskriminant fonksiyonuna göre "10.000100.000 Dolar Arası Servete Sahip Nüfus Oranı” üçüncü diskriminant fonksiyonu ile en yüksek korelasyona sahip bağımsız değişkenin "Yetişkin Başına Finansal Olmayan Servet” değişkeni ülkeleri ayırmada en fazla katkısı olan değişkenler olmuştur.

Bu açıdan "10.000 Dolar Altı Servete Sahip Nüfusun Oranı" ortalama \%95'ile en fazla ülkenin yer aldığı 2. küme olarak belirlenmiştir. "10.000 Dolar Altı Servete Sahip Nüfusun Oranı" en düşük olduğu kümeler ise sirasıyla \%23,87 ve $\% 24$ ile 4 . ve 5 . Kümelerdeki ülkelere aittir. Benzer bir tablo "10.000-100.000 Dolar Aras1 Servete Sahip Nüfusun Oranı" değişkeni için de ortaya çıkmaktadır. Bu oranın en yüksekten en düşük olduğu ülke kümeleri sıralandığında; en yüksek 5. küme, 4. küme, 1. küme, 3. küme ve 2. küme olarak sıralandığı görülmektedir.

\section{KAYNAKÇA}

Albayrak, A. S., (2006). Uygulamalı Çok Değişkenli İstatistik Teknikleri, Ankara: Asil Yayın Dağıtım.

Altuntaş, F., F., Tan, F., Z.,, (2017). "KOBİ'lerin Ortaklık Modelleri Algılamalarının Analizi: Karabük İli Örneği”, Karabük Üniversitesi Sosyal Bilimler Enstitüsü Dergisi, 7 (1), 351-394.

Boyacıoğlu, A., M., Kara Y., (2007). “Türk Bankacılık Sektöründe Finansal Güç Derecelerinin Tahmininde Yapay Sinir Ağları ve Çok Değişkenli İstatistiksel Analiz Tekniklerinin Performanslarının Karşılaştırılması" Dokuz Eylül Üniversitesi İktisadi ve İdari Bilimler Fakültesi Dergisi, Cilt:22, Say1:2, ss:197217.

Credit Suisse (2015),"Global Wealth Report”, Research Institute, October, 2015, https://www.credit-suisse.com/ch/en/about-us/research/researchinstitute/publications.html, (Erişim Tarihi:07.01.2016).

Davies, James B., Sandström, Susanna, Shorrocks Anthony B., Wolff Edward N., (2009), "The Level and Distribution of Global Household Wealth", NBER Working Paper No. 15508

Dechaume, Moncharmont, F., X.,, Monceau, K., Cezilly, F., (2011). "Sexing Birds Using Discriminant Function Analysis: A Critical Appraisal", The Auk 128(1):78-86, 2011, The American Ornithologists' Union, 2011. Printed in USA. 
Durand, Martine, Murtin, Fabrice, (2015), The Relationship Between Income and Wealth Inequality: Evidence from the New OECD Wealth Distribution Database", World Statistics Congress, Rio de Janeiro

Everitt, B., S., Landau, S.,, Leese, M., Stahl, D., (2011). Cluster Analysis, 5th Edition King's College London, UK, John Wiley \& Sons, Ltd, ISBN: 978-0-470-97780-4.

Firuzan, E., Ayvaz Y., Y., Uzun, E., (2010). “Türkiye'deki İllerin Sosyo-Kültürel Gelişmişlik Derecelerine Göre Değerlendirilmesi, TÜİK, İstatistik Araştırma Dergisi, cilt:7, Say1:2, Aralık, ss.101-128.

Görener, A., (2013), “Toplam Kalite Yönetimi Kapsamında Paydaş Memnuniyetinin İncelenmesi: Hizmet Sektöründe Bir Uygulama" İstanbul Ticaret Üniversitesi Sosyal Bilimleri Dergisi Y11:12 Say1:23 Bahar, ss.151-165.

Güngör, İ., (1999). "Kümeleme Problemlerine Küme Örtüleme Modeli Yaklaşımı ve Bir Uygulama”, D.E.Ü, İ.İ.B.F Dergisi, Cilt:14, Sayı:2. ss. 123-136.

Kalaycı, Ş., (2005), SPSS Uygulamalı Çok Değişkenli İstatistik Teknikleri. Ankara: Asil Yayın Dağıtım.

Kamışlı, M., Girginer, N., (2010). "İslem Bazlı Manipülasyonun İstatistiksel Sinıflandırma Analizleriyle Belirlenmesi." Istanbul University Econometrics and Statistics e-Journal 11.1, 1-30.

Karagül, A., A., Özdemir, B. K., (2009). "Mali Oranlar Aracılığıyla Finansal Kırılganlı̆̆ın Tekstil Sektöründeki Etkilerinin Analizi: 1992-2003 Analizi." Anadolu Üniversitesi Sosyal Bilimler Dergisi, 9.1.

Kuhn, Moritz, Schularick, Moritz, Steins, Ulrike (2017) "Income and Wealth Inequality in America, 1949-2013.", CESifo Working Paper Series No. 6608.

Oğuzlar, A., (2006). "Hanehalkı Tipi ve Kır-Kent Ayırımının Diskriminant Analizi İle İncelenmesi”, Akdeniz Universitesi Iktisadi ve Idari Bilimler Fakultesi Dergisi, 2006, 6.11.

Orthofer, Anna, (2016), "Wealth Inequality in South Africa Evidence from Survey and Tax Data", Redi 3X3, Working Paper 15.

Öz B., Taban S.,ve Kar, M., (2009). Kümeleme Analizi ile Türkiye ve AB Ülkelerinin Beşeri Sermaye Göstergeleri Açısından Karşılaştırılması. Eskişehir Osmangazi Üniversitesi Sosyal Bilimler Dergisi, 10(1).1-30

Özdamar, K. (2004). Paket Programlar ile İstatistiksel Veri Analizi (Çok Değişkenli Analizler), 5. Baskı, Kaan Kitabevi, Eskişehir.

Öztürk, İ., Yıldız, N., (2012). "n<p Boyutlu Biyolojik Verilerde Farklı Kümeleme Yöntemlerinin Karşılaştırmalı Olarak İncelenmesi”, KSÜ Doğa Bil. Dergisi, 15(4), ss. 26-36.

Richardson, David, Denniss, Richard, (2014), "Income and Wealth Inequality in Australia", The Australia Institute, Policy Brief No. 64

Saithanu, K., Jeeradid, M. , Mekparyup, J., (2014). "Prediction Of University Admission Achievement With Discriminant Model: Case Study of Phanatpittayakarn School, Chonburi, Thailand", International Electronic Journal 
of Pure and Applied Mathe affair of Phanatpittayakarn School can use these findings to predict the achievement matics - IEJPAM, Volume 8, No. 2.

Staunton, C., (2015). "The Distribution of Wealth in Ireland", TASC, December: 3-28.

Tabachnick, B., G., Fidell L., S. (2013). Using Multivariate Statistics, (6th ed.), Pearson, Boston)

Tekin, B., (2015). Temel Sağlık Göstergeleri Açısından Türkiye'deki İllerin Gruplandırılması: Bir Kümeleme Analizi Uygulaması. Çankırı Karatekin Üniversitesi İİBF Dergisi, http://dx.doi.org/10.18074/cnuiibf.196

Turanli M., Özden H. Ü., Türedi S., (2006). “Avrupa Birliği’ne Aday ve Üye Ülkelerin Ekonomik Benzerliklerinin Kümeleme Analizi İle İncelenmesi” İstanbul Ticaret Üniversitesi, Sosyal Bilimler Dergi si, Y11:5, Say1:9, Bahar 2006/1. ss. 95-108.

Uddin N., Md. Meah S., Hossain R., (2013). "Discriminant Analysis as an Aid to Human Resource Selection and Human Resource Turnover Minimization Decisions", International Journal of Business and Management; Vol. 8, No. 17; ISSN 1833-3850 E-ISSN 1833-8119 Published by Canadian Center of Science and Education.

Yaylalı M., Oktay E., Akan, Y., (2005). “Kişi Başına düşen GSYİH Değerlerine Göre Türkiye'deki Coğrafi Bölgelerin ve GSYİH'yı Oluşturan Bölgelerin Kümelenmesi”, VII. Ulusal Ekonometri ve İstatistik Sempozyumu, 26-27 Mayıs, İstanbul, ss. 1-19.

Yüksel, İ., (2004). "Çalışma Yaşamı Kalitesinin Tipik ve Atipik İstihdam Açısından İncelenmesi”, Doğuş Üniversitesi Dergisi, 5 (1), ss.47-58.

Zucman, G., (2016). "Wealth Inequality”, The Poverty and Inequality Report: 39-44

Zor, İ., ve Akın, A., (2008). "Stratejik Projeksiyonlar Bağlamında KOBİ'lerde Finansman Araçları Kullanımı", Afyon Kocatepe Üniversitesi, İIBF Dergisi, Cilt: 10, S.1, ss.177-199. 
Ek-1: 5 Aşamalı Küme Çözümü

\begin{tabular}{|c|c|c|c|c|c|c|c|c|c|c|c|c|c|c|}
\hline \multirow{2}{*}{$\begin{array}{l}\text { Ülkeler } \\
\text { 1: Arnavutluk }\end{array}$} & \multicolumn{4}{|c|}{$\begin{array}{l}5 \text { Küme } \\
\text { Çözümü }\end{array}$} & \multirow{2}{*}{$\begin{array}{l}\text { Ülkeler } \\
\text { 58: Gürcistan }\end{array}$} & \multicolumn{4}{|c|}{$\begin{array}{l}5 \text { Küme } \\
\text { Çözümü }\end{array}$} & \multirow{2}{*}{$\begin{array}{c}\text { Ülkeler } \\
\text { 115: Papua Yeni Gine }\end{array}$} & \multicolumn{4}{|c|}{$\begin{array}{l}5 \text { Küme } \\
\text { Çözümü }\end{array}$} \\
\hline & 1 & 1 & 1 & 1 & & 1 & 1 & 1 & 1 & & 2 & 2 & 2 & 1 \\
\hline 2: Cezayir & 2 & 2 & 2 & 1 & 59: Almanya & 4 & 3 & 3 & 2 & 116: Paraguay & 1 & 1 & 1 & 1 \\
\hline 3: Angola & 1 & 1 & 1 & 1 & 60: Gana & 2 & 2 & 2 & 1 & 117: Peru & 1 & 1 & 1 & 1 \\
\hline 4: Antigua ve Barbuda & 1 & 1 & 1 & 1 & 61: Yunanistan & 5 & 4 & 1 & 1 & 118: Filipinler & 1 & 1 & 1 & 1 \\
\hline 5: Arjantin & 1 & 1 & 1 & 1 & 62: Grenada & 1 & 1 & 1 & 1 & 119: Polonya & 5 & 4 & 1 & 1 \\
\hline 6: Ermenistan & 2 & 2 & 2 & 1 & 63: Gine & 2 & 2 & 2 & 1 & 120: Portekiz & 5 & 4 & 1 & 1 \\
\hline 7: Avustralya & 3 & 3 & 3 & 2 & 64: Guyana & 2 & 2 & 2 & 1 & 121: Katar & 4 & 3 & 3 & 2 \\
\hline 8: Avusturya & 4 & 3 & 3 & 2 & 65: Haiti & 2 & 2 & 2 & 1 & 122: Moldova & 2 & 2 & 2 & 1 \\
\hline 9: Azerbaycan & 1 & 1 & 1 & 1 & 66: Hong Kong & 5 & 4 & 1 & 1 & 123: Romanya & 1 & 1 & 1 & 1 \\
\hline 10: Bahamalar & 5 & 4 & 1 & 1 & 67: Macaristan & 5 & 4 & 1 & 1 & 124: Rusya Federasyonu & 2 & 2 & 2 & 1 \\
\hline 11: Bahreyn & 5 & 4 & 1 & 1 & 68: İzlanda & 3 & 3 & 3 & 2 & 125: Ruanda & 2 & 2 & 2 & 1 \\
\hline 12: Bangladeş & 2 & 2 & 2 & 1 & 69: Hindistan & 2 & 2 & 2 & 1 & 126: Saint Kitts ve Nevis & 5 & 4 & 1 & 1 \\
\hline 13: Barbados & 1 & 1 & 1 & 1 & 70: Endonezya & 1 & 1 & 1 & 1 & 127: Saint Lucia & 5 & 4 & 1 & 1 \\
\hline 14: Beyaz Rusya & 2 & 2 & 2 & 1 & 71: İran & 2 & 2 & 2 & 1 & 128: Snt. Vincent ve Gre. & 1 & 1 & 1 & 1 \\
\hline 15: Belçika & 4 & 3 & 3 & 2 & 72: İrlanda & 4 & 3 & 3 & 2 & 129: Samoa & 5 & 4 & 1 & 1 \\
\hline 16: Belize & 1 & 1 & 1 & 1 & 73: İsrail & 4 & 3 & 3 & 2 & 130: Sao Tome ve Principe & 2 & 2 & 2 & 1 \\
\hline 17: Benin & 2 & 2 & 2 & 1 & 74: İtalya & 4 & 3 & 3 & 2 & 131: Suudi Arabistan & 5 & 4 & 1 & 1 \\
\hline 18: Bolivya & 2 & 2 & 2 & 1 & 75: Jamaika & 1 & 1 & 1 & 1 & 132: Senegal & 2 & 2 & 2 & 1 \\
\hline 19: Bosna-Hersek & 1 & 1 & 1 & 1 & 76: Japonya & 4 & 3 & 3 & 2 & 133: Surbistan & 2 & 2 & 2 & 1 \\
\hline 20: Botsvana & 2 & 2 & 2 & 1 & 77: Ürdün & 1 & 1 & 1 & 1 & 134: Seyşeller & 1 & 1 & 1 & 1 \\
\hline 21: Brezilya & 1 & 1 & 1 & 1 & 78: Kazakistan & 2 & 2 & 2 & 1 & 135: Sierra Leone & 2 & 2 & 2 & 1 \\
\hline 22: Brunei & 5 & 4 & 1 & 1 & 79: Kenya & 2 & 2 & 2 & 1 & 136: Singapur & 4 & 3 & 3 & 2 \\
\hline 23: Bulgaristan & 5 & 4 & 1 & 1 & 80: Kuveyt & 5 & 4 & 1 & 1 & 137: Slovakya & 5 & 4 & 1 & 1 \\
\hline 24: Burkina Faso & 2 & 2 & 2 & 1 & 81: Kırgızistan & 2 & 2 & 2 & 1 & 138: Slovenya & 5 & 4 & 1 & 1 \\
\hline 25: Burundi & 2 & 2 & 2 & 1 & 82: Lao Halk Dem.Cum. & 2 & 2 & 2 & 1 & 139: Solomon Adalar1 & 1 & 1 & 1 & 1 \\
\hline 26: Kamboçya & 2 & 2 & 2 & 1 & 83: Letonya & 5 & 4 & 1 & 1 & 140: Güney Afrika & 1 & 1 & 1 & 1 \\
\hline 27: Kamerun & 2 & 2 & 2 & 1 & 84: Lübnan & 1 & 1 & 1 & 1 & 141: İspanya & 5 & 4 & 1 & 1 \\
\hline 28: Kanada & 4 & 3 & 3 & 2 & 85: Lesoto & 2 & 2 & 2 & 1 & 142: Sri Lanka & 2 & 2 & 2 & 1 \\
\hline 29: Cape Verde & 1 & 1 & 1 & 1 & 86: Liberya & 2 & 2 & 2 & 1 & 143: Sudan & 2 & 2 & 2 & 1 \\
\hline 30: Mrk.Afrika Cum & 2 & 2 & 2 & 1 & 87: Libya & 1 & 1 & 1 & 1 & 144: Surinam & 2 & 2 & 2 & 1 \\
\hline 31: Çad & 2 & 2 & 2 & 1 & 88: Litvanya & 5 & 4 & 1 & 1 & 145: Svaziland & 2 & 2 & 2 & 1 \\
\hline 32: Șili & 5 & 4 & 1 & 1 & 89: Lüksemburg & 3 & 3 & 3 & 2 & 146: İsveç & 4 & 3 & 3 & 2 \\
\hline 33: Çin & 1 & 1 & 1 & 1 & 90: Madagaskar & 2 & 2 & 2 & 1 & 147: İsviçre & 3 & 3 & 3 & 2 \\
\hline 34: Kolombiya & 1 & 1 & 1 & 1 & 91: Malavi & 2 & 2 & 2 & 1 & 148: Suriye Arap Cum. & 2 & 2 & 2 & 1 \\
\hline 35: Komorlar & 2 & 2 & 2 & 1 & 92: Malezya & 1 & 1 & 1 & 1 & 149: Tacikistan & 2 & 2 & 2 & 1 \\
\hline 36: Kongo & 2 & 2 & 2 & 1 & 93: Maldivler & 2 & 2 & 2 & 1 & 150: Tayland & 2 & 2 & 2 & 1 \\
\hline 37: Kosta Rika & 5 & 4 & 1 & 1 & 94: Mali & 2 & 2 & 2 & 1 & 151: Makedonya FYR & 1 & 1 & 1 & 1 \\
\hline 38: Fildişi Sahilleri & 2 & 2 & 2 & 1 & 95: Malta & 5 & 4 & 1 & 1 & 152: Togo & 2 & 2 & 2 & 1 \\
\hline 39: Hirvatistan & 5 & 4 & 1 & 1 & 96: Moritanya & 2 & 2 & 2 & 1 & 153: Tonga & 1 & 1 & 1 & 1 \\
\hline 40: Kibris & 5 & 4 & 1 & 1 & 97: Mauritius & 5 & 4 & 1 & 1 & 154: Trinidad ve Tobago & 5 & 4 & 1 & 1 \\
\hline 41: Cek Cum. & 5 & 4 & 1 & 1 & 98: Meksika & 1 & 1 & 1 & 1 & 155: Tunus & 1 & 1 & 1 & 1 \\
\hline 42: Dem. Kongo Cum. & 2 & 2 & 2 & 1 & 99: Moğolistan & 1 & 1 & 1 & 1 & 156: Türkiye & 1 & 1 & 1 & 1 \\
\hline 43: Danimarka & 3 & 3 & 3 & 2 & 100: Karadağ & 5 & 4 & 1 & 1 & 157: Türkmenistan & 5 & 4 & 1 & 1 \\
\hline 44: Cibuti & 2 & 2 & 2 & 1 & 101: Fas & 1 & 1 & 1 & 1 & 158: Uganda & 2 & 2 & 2 & 1 \\
\hline 45: Dominika & 5 & 4 & 1 & 1 & 102: Mozambik & 2 & 2 & 2 & 1 & 159: Ukrayna & 2 & 2 & 2 & 1 \\
\hline 46: Ekvator & 1 & 1 & 1 & 1 & 103: Myanmar (Burma) & 2 & 2 & 2 & 1 & 160: Birleşik Arap Emirlikleri & 4 & 3 & 3 & 2 \\
\hline 47: Misır & 2 & 2 & 2 & 1 & 104: Namibya & 2 & 2 & 2 & 1 & 161: Birleşik Krallık & 4 & 3 & 3 & 2 \\
\hline 48: El Salvador & 1 & 1 & 1 & 1 & 105: Nepal & 2 & 2 & 2 & 1 & 162: Tanzanya & 2 & 2 & 2 & 1 \\
\hline 49: Ekvator Ginesi & 1 & 1 & 1 & 1 & 106: Hollanda & 4 & 3 & 3 & 2 & 163: A.B.D. & 4 & 3 & 3 & 2 \\
\hline 50: Eritre & 2 & 2 & 2 & 1 & 107: Yeni Zelanda & 4 & 3 & 3 & 2 & 164: Uruguay & 5 & 4 & 1 & 1 \\
\hline 51: Estonya & 5 & 4 & 1 & 1 & 108: Nikaragua & 2 & 2 & 2 & 1 & 165: Vanuatu & 2 & 2 & 2 & 1 \\
\hline 52: Etiyopya & 2 & 2 & 2 & 1 & 109: Nijer & 2 & 2 & 2 & 1 & 166: Venezuela & 2 & 2 & 2 & 1 \\
\hline 53: Fiji & 2 & 2 & 2 & 1 & 110: Nijerya & 2 & 2 & 2 & 1 & 167: Vietnam & 2 & 2 & 2 & 1 \\
\hline 54: Finlandiya & 4 & 3 & 3 & 2 & 111: Norveç & 3 & 3 & 3 & 2 & 168: Yemen & 2 & 2 & 2 & 1 \\
\hline 55: Fransa & 4 & 3 & 3 & 2 & 112: Umman & 5 & 4 & 1 & 1 & 169: Zambiya & 2 & 2 & 2 & 1 \\
\hline 56: Gabon & 1 & 1 & 1 & 1 & 113: Pakistan & 2 & 2 & 2 & 1 & 170: Zimbabwe & 2 & 2 & 2 & 1 \\
\hline 57: Gambiya & 2 & 2 & 2 & 1 & 114: Panama & 1 & 1 & 1 & 1 & 171: Tayvan & 4 & 3 & 3 & 2 \\
\hline
\end{tabular}




\section{Global Wealth Inequality and Multinational Classification}

\author{
Ercan YAŞAR \\ Dumlupınar Üniversitesi \\ Faculty of Economics and Administrative \\ Sciences, Kütahya, Turkey \\ orcid.org/0000-0002-9471-4068 \\ ercan.yasar@dpu.edu.tr
}

Mine YAŞAR

orcid.org/0000-0002-1974-4240

mine-demircelik@hotmail.com

\section{Extensive Summary}

\section{Introduction}

Wealth is often associated with money, savings, investments, owned houses and cars or other forms of financial capital. The wealth of a person or a household is measured by the assets they own. But one's total wealth (or net wealth) also includes debts at the same time. It differs from the concept of income in this regard. While income is flow variable, wealth is stock variable. Although wealth is more unevenly distributed than income, wealth inequality is directly related to income inequality. Asset types seen as wealth; the land, real estate, agricultural assets, vehicles, cash savings, life insurance accumulations, pension funds and personal property are included (Staunton, 2015, pp. 4).

In this study, inequalities in the distribution of wealth at the global level were put forward and it was attempted to explain that global wealth, like other socioeconomic inequalities, displayed a similar appearance. In the study, it is aimed to identify similar countries with wealth distribution by moving from global wealth inequality and global distribution of household wealth. On the other hand, it is aimed to monitor the differences between the wealth composition of households in underdeveloped, developing and developed countries. In line with these basic objectives; It was aimed to determine the characteristics of countries with similar wealth structures for 171 countries. According to the similarities between the units studied in the study, clustering analysis method was used to collect and classify within certain groups, to reveal the common characteristics of the units and to make general definitions about these classes. In the last part of the study, Discriminant Analysis was applied to determine the significance of the groups obtained by the Cluster Analysis Method and the variables that are effective in group distinctions.

\section{Methodology}

Multidimensional statistical methods need to be used to determine the relative situations of the countries' global wealth composition to each other. Hierarchical Cluster Analysis method was applied to distinguish countries to groups. In addition, Ward technique was applied when the data set was standardized between -1 and +1 in the analysis and the variables were analyzed according to the euclidean square distances. In order to examine the global wealth distribution, 10 different variables were used, compiled from Credit Suisse's 2016 Global Wealth Report. According to the dendrogram results related to cluster membership, it was deemed appropriate to consider the countries in 5 clusters. 
To identify the significance of the determined groups Discriminant Analysis method was used. Discriminant Analysis shows how well the set clustering variables achieve the cluster of the countries studied. The main difference that separates the Discriminant Analysis from the Clustering Analysis is that the groups are known in advance in the Discriminant Analysis (Özdamar, 2004, ss. 355-356).

In this study, wealth data of countries are taken into consideration and Ward cluster method which is one of the hierarchical clustering methods is chosen. Classical clustering methods do not give the number of clusters in previously. Dendograms and graphical methods are used to determine the number of clusters. 5 cluster solutions obtained by Ward Clustering analysis are given. (Tekin, 2015, s. 14).

\section{Findings}

As a result of the clustering analysis, it can be seen in dendogram 10 variables associated with wealth of 171 countries differentiated in 5 clusters. Looking at the dendogram, it can be said that 5 units are suitable. When the number of clusters was investigated by graphical method, 2 clusters were solved first, then 3 clusters were solved and the other clusters were tested until the integrity was broken and finally 5 clusters solution was decided. In the obtained dendrogram, it was determined that the 3rd and 4th clusters formed a common cluster according to the dendogram in the two cluster solutions. 1st, 2nd and the 5th cluster constituted the other common second cluster. In the three cluster solution, it is seen that the 1 st and 5 th clusters form a single cluster and the 3rd and 4th clusters form a single cluster. Finally, it is observed that the 2nd cluster form a single cluster.Cluster memberships are seen in the following table 1.

The success of the discriminant analysis depends on the correct classification percentage; the higher the rate, the more successful the analysis is. When the results are examined, it is seen that 165 of the 171 countries $(96.5 \%)$ are correctly classified. The total correct classification percentage of the discriminant function is highly successful. From the functions obtained as a result of analysis; 38 of the 40 observing units in the first cluster are assigned correctly and 2 are incorrectly classified. All 73 observing units in the 2 nd cluster are correctly assigned. 5 of the 6 observing units in the 3 rd cluster are incorrect and 1 in the correct cluster. All 19 observations in the 4th cluster are assigned to the correct cluster. Finally, 30 of the 33 countries in the 5 th cluster are placed correctly and 3 countries placed incorrectly. $96.5 \%$ of the cluster memberships estimated in line with these results are estimated correctly. The second best cluster probabilities of erroneous cluster placements are estimated correctly. Thus, according to the variables used in the study, it can be stated that 171 countries can be expressed significantly in 5 different clusters according to global wealth indicators. 


\section{Table 1: Memberships of Clusters}

\begin{tabular}{|c|c|}
\hline $\begin{array}{l}\text { 1st Cluster } \\
\text { (40 Members) }\end{array}$ & $\begin{array}{l}\text { Albania, Angola, Antigua and Barbuda, Argentina, Azerbaijan, Barbados, Belize, Bosnia and } \\
\text { Herzegovina, Brazil, Cape Verde, China, Colombia, Ecuador, El Salvador, Ecuador Ginesi, } \\
\text { Gabon, Georgia, Grenada, Indonesia, Jamaica, Jordan, Lebanon, Libya, Malaysia, Mexico, } \\
\text { Mongolia, Morocco, Panama, Paraguay, Peru, Philippines, Romania, Saint Vincent and the } \\
\text { Grenadines, Seychelles, Solomon Islands , South Africa, Macedonia Cum., Tonga, Tunisia, } \\
\text { Turkey. }\end{array}$ \\
\hline $\begin{array}{l}\text { 2nd Cluster } \\
\text { ( } 73 \text { Members) }\end{array}$ & $\begin{array}{l}\text { Algeria, Armenia, Bangladesh, Belarus, Benin, Bolivia, Botswana, Burkina Faso, Burundi, } \\
\text { Cambodia, Cameroon, Mr. Africa Cum., Chad, Comoros, Congo, Ivory Coast, Dem. Congo } \\
\text { Cum., Djibouti, Egypt, Eritrea, Ethiopia, Fiji, Gambia, Ghana, Guinea, Guyana, Haiti, India, } \\
\text { Iran, Kazakhstan, Kenya, Kyrgyzstan, Lao People's Dem. Cum., Lesotho, Liberia, Madagascar, } \\
\text { Malawi, Maldives, Mali, Mauritania, Mozambique, Myanmar (Burma), Namibia, Nepal, } \\
\text { Nicaragua, Niger, Nigeria, Pakistan, Papua New Guinea, Moldova, Russian Federation, } \\
\text { Rwanda, Sao Tome and Principe, Senegal, Serbia, Sierra Leone, Sri Lanka, Sudan, Suriname, } \\
\text { Swaziland, Syria, Tajikistan, Thailand, Togo, Uganda, Ukraine, Tanzania, Vanuatu, } \\
\text { Venezuela, Vietnam, Yemen, Zambia, Zimbabwe. }\end{array}$ \\
\hline $\begin{array}{l}\text { 3rd Cluster } \\
(6 \text { Members })\end{array}$ & Australia, Denmark, Iceland, Luxembourg, Norway, Switzerland. \\
\hline $\begin{array}{l}\text { 4th Cluster } \\
\text { (19 Members ) }\end{array}$ & $\begin{array}{l}\text { Austria, Belgium, Canada, Finland, France, Germany, Ireland, Israel, Italy, Japan, Netherlands, } \\
\text { New Zealand, Qatar, Singapore, Sweden, United Arab Emirates, United Kingdom, United } \\
\text { States, Taiwan. }\end{array}$ \\
\hline $\begin{array}{l}\text { 5th Cluster } \\
\text { (33 Members) }\end{array}$ & $\begin{array}{l}\text { Bahamas, Bahrain, Bulgaria, Chile, Costa Rica, Croatia, Cyprus, Czech Republic, Dominica, } \\
\text { Estonia, Greece, Hong Kong, Hungary, Kuwait, Latvia, Lithuania, Malta, Mauritius, } \\
\text { Montenegro, Oman, Poland, Portugal, Saint Kitts And Nevis, Saint Lucia, Samoa, Saudi } \\
\text { Arabia, Slovakia, Slovenia, Spain, Trinidad and Tobago, Turkmenistan, Uruguay. }\end{array}$ \\
\hline
\end{tabular}

\section{Conclusion and Discussion}

The results of the Clustering Analysis which conducted with 10 different variables that are indicative of country wealth accumulation according to the Credit Suisse's Global Wealth Report (2016), show that countries can be classified in 5 different clusters according to global wealth components. According to the clustering analysis used by the Ward method, it can be seen that the developed European countries and the United States occupied in the same cluster (4th Cluster) and at the same time the oil rich Qatar and the United Arab Emirates took place in this cluster.

It appears that South America's east is formed by the 2nd cluster, including the Russian Federation and Kyrgyzstan, where African countries are often located. It is seen that Turkey was formed by the 1st cluster in which it was included, and finally Eastern European countries and some Central and South East Asian countries. For these results, it can be said that the clustering results are in parallel with the development level. However, in the results, the answer of the question that "why the 3rd cluster is separated from the 4th cluster" should be revealed by more detailed analyzes. 